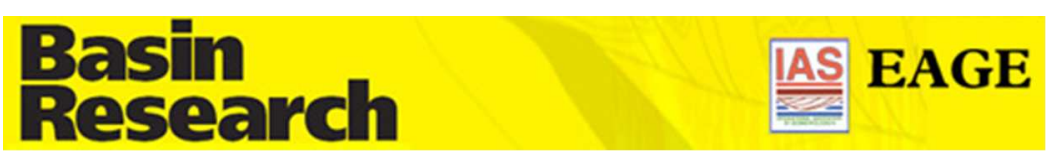

\title{
Linking sedimentation rates and large-scale architecture for facies prediction in non-marine basins. (Paleogene, Almazán Basin, Spain)
}

\begin{tabular}{|r|l|}
\hline Journal: & Basin Research \\
\hline Manuscript ID: & BRE-120-2014.R1 \\
\hline Manuscript Type: & Original Article \\
\hline Date Submitted by the Author: & n/a \\
\hline Complete List of Authors: & $\begin{array}{l}\text { VALERO, LUIS; University of Barcelona, Stratigraphy, Paleontology and } \\
\text { Marine Geosciences } \\
\text { Huerta, Pedro; University of Salamanca, Geology } \\
\text { Garcés, Miguel; University of Barcelona, Stratigraphy, Paleontology and } \\
\text { Marine Geosciences } \\
\text { Armenteros, Ildefonso; University of Salamanca, Geology } \\
\text { Beamud, Elisabet; ICTJA, Laboratori de Paleomagnetisme } \\
\text { Gómez-Paccard, Miriam; ICTJA, }\end{array}$ \\
\hline Keywords: & $\begin{array}{l}\text { tectonics and sedimentation, stratigraphy, sedimentology, sequence } \\
\text { stratigraphy, magnetostratigraphy }\end{array}$ \\
\hline
\end{tabular}

\section{SCHOLARONE ${ }^{\text {m }}$}

Manuscripts 


\title{
Linking sedimentation rates and large-scale architecture for facies
} prediction in non-marine basins. (Paleogene, Almazán Basin, Spain)

\author{
Valero L. ${ }^{1}$, Huerta P. ${ }^{2}$, Garcés M. ${ }^{1}$, Armenteros, I. ${ }^{3}$, Beamud, E. ${ }^{4}$, Gómez-Paccard, M. ${ }^{5}$ \\ 1: Dept. d'Estratigrafia, Paleontologia i Geociencies Marines, Facultat de Geologia, Universitat de \\ Barcelona, 08028, Barcelona, Spain \\ 2: Dept. Geología, Universidad de Salamanca, Escuela Politécnica Superior de Ávila, 05003-Ávila, Spain 3: \\ Dept. Geología, Universidad de Salamanca, Facultad de Ciencias 37071-Salamanca, Spain \\ 4: Laboratori de Paleomagnetisme CCiTUB-ICTJA CSIC, 08028- Barcelona, Spain \\ 5: Géosciences-Rennes, UMR 6118, Université de Rennes 1, Campus de Beaulieu, Bât. 6 15, CS 74205, \\ 35042 Rennes, France.
}

\section{0.- ABSTRACT}

This paper focuses on the relationships between the large-scale stratigraphic architecture of the Almazán basin infill and the sedimentation rates (SR) calculated for precise time intervals. Our aim is to improve the understanding of the timing and causes of the architectural changes, their significance in terms of accommodation space and sediment supply, and their relationship with climate and tectonics. The study area includes the Gómara fluvial fan, the main sediment transfer system of the Almazán basin during Paleogene times. Its large-scale architecture shifted through time between a stacking pattern of low density ribbon-like and high density sheet-like channel fills. Laterally to the fluvial system, mudstone and evaporitic mudstone units represented evaporitic mudflats which passed laterally into palustrine/lacustrine limestone units interpreted as lakes and ponds. Stacked calcretes occurred in distal alluvial and distal floodplain settings. A magnetostratigraphy encompassing 2600 meters guided by available fossil mammal biochronology has provided a temporal framework that spans the complete Paleogene infill of the basin, from Late Lutetian to Late Oligocene, filling a gap in the Cenozoic chronostratigraphy of Spanish basins. This permits to constrain the kinematics of the structures both in the basin and in its margins, and to provide the timing for the depositional sequences. These data, combined with a magnetostratigraphic map, where magnetic reversals were traced through the Gómara monocline, allow a detailed analysis of the SR variability across the fluvial system and its adjacent depositional environments. The results show that high sedimentation rates (around $30-40 \mathrm{~cm} / \mathrm{kyr}$ ) are related to fluvial environments with low density ribbon-shaped channels, while low SR (around or below $10 \mathrm{~cm} / \mathrm{kyr}$ ) are related to high density sheet-like channels. Laterally, mud dominated environments with high SR $(15-20 \mathrm{~cm} / \mathrm{kyr})$ grade into palustrine/lacustrine carbonated environments with low SR (around $9 \mathrm{~cm} / \mathrm{ky}$ ). The lowest SR (about $3 \mathrm{~cm} / \mathrm{kyr}$ ) are related to the development of stacked calcrete profiles in distal floodplain and in the connection of distal alluvial and palustrine/lacustrine units.

\section{1.- INTRODUCTION}


The development of sequence stratigraphy has provided a framework for basin-wide correlations, interpretation and prediction of sedimentary facies and environments (Mitchum et al., 1977; Vail \& Mitchum, 1977; Posamentier, 1988; Van Wagoner et al., 1988; Catuneanu, 2006). A large number of studies have focused on the variations of large-scale architecture of fluvial systems in order to understand why, where and when highly interconnected fluvial channels occur (Bridge \& Leeder, 1979; Shanley \& McCabe, 1991; Wright \& Marriott, 1993; Mackey \& Bridge, 1995; Legarreta \& Uliana, 1998; Sheets et al., 2002; Hickson et al., 2005).

The architectural arrangement of the sedimentary record in non-marine basins is the response to the interplay between accommodation space and sediment supply (Catuneanu et al., 2009). The main allogenic factors driving changes in accommodation space and sediment supply are tectonics and climate, which also modify the slope of the system (Catuneanu \& Elango, 2001), the avulsion rate (Bryant et al., 1995; Heller \& Paola, 1996), the bypass ratio, and the amount of sediment extracted along the sediment transport system (Strong et al., 2005; Paola \& Martin, 2012; Michael et al., 2014). Here, we hypothesize that the characterization of the large-scale architectural arrangement together with quantification of sedimentary rates can help assessing the relative role of accommodation and sediment supply in basin infill history.

Understanding the main controls on the occurrence of highly interconnected sheet like channels is highly important for oil industry, groundwater exploration, and for $\mathrm{CO}_{2}$ storage in non-marine basins because it could help reservoir prediction (Huerta et al., 2011). This paper is focused on the calculation of sedimentation rates and the subsequent comparison with the large-scale architectural elements of the Almazán Basin, including fluvial, mudflat, palustrine and lacustrine sedimentary systems. The Paleogene record of the Almazán Basin is particularly suitable to perform this analysis because it integrates most of the continental environments with well-exposed vertical and lateral relationships. The basin shows an outstanding outcrop exposure, which permits three-dimensional reconstructions. To undertake these objectives, the alluviallacustrine and fluvial succession ( $c a .2700 \mathrm{~m}$ ) in the Gómara monocline has been dated by means of magnetostratigraphy. Magnetic polarity reversals have been mapped along the monocline, and sedimentation rates have been calculated for four key transects in order to assess their lateral changes in relation to different sedimentary environments and basin settings. The new chronostratigraphy of the basin infill can be used to derive a robust time frame for biostratigraphic calibration, and to analyse the tectonosedimentary relationships and the uplift history of the basin.

\section{2.- BACKGROUND}

\subsection{Sedimentary Architecture and Sedimentation Rates}

The architectural changes in both the fluvial systems and their lateral equivalents are often interpreted in terms of changes in the accommodation or in the ratio between accommodation and sediment supply (Muto and Steel, 1997; Carrol and Bohacs, 1999; Bohacs et al., 2000; Huerta et al., 2011). This is a basic assumption of sequence stratigraphy, which contributed to an efficient interpretation of the evolution of depositional systems (Catuneanu et al., 2009). We took the definition of 
accommodation provided in Muto and Steel (2000) in which accommodation is seen as "the thickness, measured at a specified site and time, of a space which becomes filled with sediments during a specified time interval". This definition is practical to quantify because it is equivalent to sedimentation rates. Sediment supply is considered to be the volume of sediment delivered to a certain place of the basin in a given time (sediment deposited + sediment bypassed). This value is difficult to estimate from field data in ancient sedimentary systems. We use the classification of high- and lowsediment supply areas provided in Huerta et al., (2011).

Changes in the large-scale architecture of depositional systems are usually associated to changes in accommodation. Spatial and temporal variability of accommodation leads to a complex interaction throughout sediment distributive systems, affecting the localization of sedimentary environments, the bypass rate, the avulsion frequency and the slope in clastic systems, which also modify the sediment supply. To correctly understand the triggers of changes in large-scale architecture it is therefore needed to identify the accommodation and sediment supply interplay. The ratio between accommodation space and sediment supply (AS/SS) is, however, relative, because field estimations of sediment supply are hardly quantifiable. Relativeness of the AS/SS ratio can be reduced pinning accommodation between intervals sharing sedimentation rates. This allows observing the influence of sediment supply variations in both the large-scale architectural arrangement and the shifts between depositional environments. The LAB models (Leeder-Allen-Bridge; Allen, 1978; Bridge \& Leeder, 1979) and most studies in ancient sedimentary records show that an increase in accommodation in fluvial settings is related to prevalence of isolated and narrow channels. There are, however, other factors such as the avulsion frequency that should be taken into account. If the avulsion frequency grows faster than sediment accumulation, it can produce high channel interconnection (Heller \& Paola, 1996). In addition, some field studies disagree about the inverse relationship between channel density and accommodation space (Tornqvist, 1994; Colombera et al, 2015). Beyond accommodation, we consider the ratio AS/SS, in order to assess the relative influence of sediment supply in the architectural changes.

The external causes affecting the ratio AS/SS in internally drained non-marine basins are climate and tectonics. Climate forcing can be assessed by means of identification of Milankovitch cycles (Hilgen et al., 2014). However, orbital cycles might not be expressed in the sedimentary record if the environment is not sensitive enough or if the tectonic signal is outweighed. Alternatively, another option is to discriminate the slight differences between climate and tectonics in the sedimentary record. Climate, by means of precipitation and evaporation changes, leads to lateral and longitudinal variations of the sediment grain size (Armitage et al., 2011). On the other hand, tectonics can directly affect accommodation space (AS). Models show that an increase of AS results into coarser grain size accumulation in the proximal sites, followed by a reduction in grain size in distal locations (Armitage et al., 2011; Paola \& Martin, 2012). However, in non-marine basins, changes in precipitation and or evaporation may modify the accommodation by base level rise or fall. In parallel, tectonics may change SS by promoting uplift and drainage changes in the catchment areas. 


\subsection{Geological Setting}

The Almazán Basin in north-central Spain is a thick-skinned piggy-back basin bounded by the Cameros Massif and the Aragonian and Castilian branches of the Iberian Chain (Fig. 1A). It developed on the hanging wall of the Cameros thrust, which moved northwards over the Cenozoic deposits of the Ebro Basin, producing the uplift of the Cameros Massif and the Iberian Chain during the Alpine orogeny (Casas, 1990; CasasSainz, 1993; Muñoz-Jiménez \& Casas-Sainz, 1997). The Cameros massif is mainly composed by Upper Jurassic-Lower Cretaceous siliciclastics and carbonates, and the Aragonian branch of the Iberian Chain by Mesozoic carbonates and minor evaporites, with a metamorphic Paleozoic basement. Most of the sediment was delivered from these areas, while the Castilian branch of the Iberian Chain only supplied minor amounts of sediment (Huerta, 2007). During the Paleogene, the Almazán Basin was a non-marine isolated basin, which connected towards the west with the Duero Basin during Neogene times through the Aranda-Burgo de Osma corridor (Armenteros \& Huerta, 2006).

The Almazán Basin has a flat-bottomed syncline geometry filled by Paleogene and Neogene non-marine deposits, reaching a maximum total thickness of more than 3500 meters at its depocentre (Fig. 1B). The depocentre is bounded by the Almazán and Arcos monoclines towards the south, and the Gómara monocline and the Aragonian branch of the Iberian Chain towards the north (Casas-Sainz et al., 2000). The activity of these structures was synchronous to sedimentation, controlling the distribution and thickness of the stratigraphic units that filled the basin.

\subsection{Sequence stratigraphy}

Detailed mapping (scale 1:25000), stratigraphic correlations and seismic interpretation in the Almazán Basin were carried out in earlier studies (Huerta, 2007). Further detailed sedimentological, mineralogical and geochemical analyses were performed in the fluvial, lacustrine and playa-lake systems (Huerta et al., 2010; Huerta et al., 2011). On the basis of these studies the complete Paleogene basin infill is divided into four Depositional Sequences (A1 to A4 in Fig. 1). These sequences overlie an unconformity characterised by a hiatus that encompasses from Upper Cretaceous to lower Bartonian, and minor erosion of the Upper Cretaceous marine limestones.

Depositional Sequence A1 crops out close to the northern and eastern basin margins. It reaches a maximum thickness of $400 \mathrm{~m}$, which gradually reduces towards the south and southeast. This sequence denotes a retrogradation from conglomeratic alluvial deposits passing into distal alluvial plains dominated by calcretes and shallow carbonate-precipitating lakes. The Mazaterón mammal fossil site (MP 15-16, Jiménez \& Cuesta, 1994) is located at the top of this sequence.

Depositional Sequence A2 crops out principally in the northern domain of the basin, with a maximum thickness of $900 \mathrm{~m}$ that wedges out towards the south. The base of the sequence is marked by a change in the sedimentation trend from retrogradational to progradational. A2 expanded southwards on Upper Cretaceous basement rocks, reaching the opposite basin margin. 
Depositional Sequence A3 can be observed in the Gómara monocline and in the Torlengua anticline (Fig. 1). It reaches a thickness of $1100 \mathrm{~m}$, wedging out towards the south and southeast, and displaying a progradational trend. The base of the sequence consists of an unconformity, which changes basinwards into a correlative conformity marked by calcretes and gypcretes, indicating a retrogradational trend of the fluvial system. Close to the Aragonian branch, in the Southeast domain (Deza-Embid), its lower boundary consists of an unconformity covering A2 and Upper Cretaceous limestones. Its thickness is notably reduced towards the upper limb of the Gómara monocline (Northern Domain) and on the upper limb of the Almazán monocline at the south of the basin.

Depositional Sequence A4 is covered by undeformed Neogene units, with the exception of few outcrops along the Gómara monocline. In contrast to older Paleogene depositional sequences, it becomes thicker southwards and displays syntectonic unconformities at the basin margins. This sequence is articulated in the Gómara monocline and records the exhumation of the northern domain, evidenced by the occurrence of Paleogene clasts.

\subsection{Tectonic domains}

The structural framework of the Almazán Basin is divided into five principal tectonic domains (Fig. 1): i) the northern domain; ii) the Almazán and Arcos monoclines; iii) the south-eastern domain; iv) the Gómara monocline; and v) the basin depocentre. A description of the tectonic domains and their structures is provided, except for the basin depocentre, which steadily subsided during all the Paleogene and Neogene history.

The northern domain of the basin (i) records the maximum thickness of $A 1$ and $A 2$. A3 is only preserved in the core of two synclines, and A4 is absent (Huerta et al., 2011). This domain is bounded by the Sierra de la Pica Thrust or South Cameros Thrust (Navarro Vázquez, 1991; Guimerà et al., 1995) towards the North, and the Gómara monocline towards the South (Fig. 1). It is affected by NW-SE trending folds plunging towards the NW, which at the same time were affected by perpendicular minor folds. The NW-SE anticlines are bounded by thrusts towards the north, along the Aragonian branch of the Iberian Range.

The Almazán and Arcos monoclines (ii) are located in the southern part of the basin, and are only recognizable in subsurface (Casas-Sainz et al., 2002). These monoclines are WNW-ESE oriented, are related to faults affecting the Paleozoic basement, and dip $15^{\circ}$ to $45^{\circ}$ northwards. Folding started during A3 (adapting the Casas-Sainz et al., 2002 unit boundaries to our sequence stratigraphic framework), producing a structural relief of about $2000 \mathrm{~m}$ in the case of the Almazán monocline (Casas-Sainz et al., 2002). During the initial stages of the monocline development, limb rotation occurred, this evidenced by thickness reduction towards the upper limb. During $A 3$ and $A 4$ deposition, the monoclines developed by kink band migration showing excellently preserved growth strata (Casas-Sainz et al., 2002), displaying important thickness reduction in their upper limb. 
The south-eastern domain (iii) is characterized by a thickness decrease of the Paleogene succession with respect to the Gómara monocline. The A2/A3 and A3/A4 boundaries are marked by unconformities, and important local alluvial fan deposits occur in every depositional sequence boundary in this domain. The La Alameda-Tapiela anticline/thrust (this nomenclature is used for folds that in some parts evolved into thrusts) supplied with sediments the local alluvial fan systems. Southwards, the development of the Torlengua anticline folded the A4 sequence in its northern limb.

The Gómara monocline (iv) was generated in response to the development of the La Alameda-Tapiela anticline/thrust. It connects the northern domain with the basin depocentre. It has NW-SE trend, dips $30^{\circ}$ southwards, and generated a structural relief of about $2500 \mathrm{~m}$. Towards the SE, around the Deza area (Fig. 1; Fig. 2), the monocline evolved into a succession of folds. As a consequence, all the Paleogene depositional sequences (A1-A4) were folded, and also a thickness reduction in $A 3$ towards the upper limb of the monocline is observed. A4 has a wedge shape that articulated in this monocline, opening southwards. The outcrops of this structure show a cross-section perpendicular to the main drainage system of the basin.

\section{3.-METHODS}

\subsection{Channel density calculations}

The channel interconnection or channel density has been quantified mapping the channel fills and the overbank deposits in outcrops of the Gómara monocline. The Channel density is taken as the percentage of the surface in a fluvial succession occupied by channel fills. Eight representative boxes or rectangles of $0.350 \mathrm{~km} 2$ were drawn in a GIS with its long side parallel to stratification (Fig. 3; Fig. 4). The size of the boxes was in the large-scale size of the fluvial architecture in the sense of Leeder (1993) and Jo \& Chough (2001). Four were drawn on the Depositional Sequence A2 and four in $A 3$, to have a representation of the channel density of the end-members identified in the fluvial succession. The results are represented in the Table 1 (The mapped boxes are available as supplementary material).

\subsection{Magnetostratigraphy}

Paleomagnetic sampling was performed with an electrical portable drill along the two overlapping Almazul and Mazaterón sections (Fig. 2), encompassing a total thickness of 2670 meters. The sampled interval included the alluvial Almazul Fm., the lacustrine/palustrine Mazaterón Fm., and the fluvial Gómara Fm. (Fig.2). Representative sampled lithologies included red and orange mudstones (mainly), very fine sandstones, limestones and marls (occasionally). An optimal sampling transect was chosen to include the most expanded sections with higher abundance of fine grained lithologies, the best outcrop exposures, and stratigraphic continuity. Two cores per site were drilled with an average spacing of 10 meters/site, collecting a total of 269 sites.

Samples were analysed in the paleomagnetic laboratories of Fort Hoofdijk (Utrecht University) and the Institute of Earth Sciences Jaume Almera (CCiTUB-ICTJA CSIC). The Natural Remanent Magnetisation (NRM) was measured on DC SQUID superconducting 
rock magnetometers (2G Enterprises Ltd). Stepwise thermal increments were of $50^{\circ} \mathrm{C}$ up to $350^{\circ} \mathrm{C}$, and of $30^{\circ} \mathrm{C}$ up to the maximum unblocking temperature of samples. Magnetic susceptibility was measured with a KLY-2 susceptibility bridge (Agico) at each demagnetization step in order to monitor mineralogical changes during heating.

\subsection{Isochrons map and SR calculations}

Magnetostratigraphy provided the location of magnetic reversals for the sampled section. Prominent and laterally continuous beds can be interpreted as isochrones within the magnetostratigraphic temporal resolution. The lateral extension of the reversals was inferred by means of key beds (Fig. 2), which allowed mapping the reversals along the study area. When channels are wide and interconnected or when continuous limestone beds crop out, the mapping results straightforward. However, within mudflats deposits the precision of the correlation decreases. In spite of this, the correlation was possible for the most of the monocline, allowing a fine evaluation of stratigraphic thickness variations across the Paleogene record of the Gómara monocline.

Mapping of the magnetic reversals allows the quantification of Sedimentation Rates (SR) for different time intervals (Johnson et al., 1988). Direct measurements were performed along the Miñana section, which is representative of the fluvial system. In this case, the ratio between sediment accumulated and time directly gives SR. Additionally, SR were estimated in 3 other key transects in order to assess the SR variability related to sedimentary environments and basin locations. For these sections, SR were estimated after geometrical calculation of thicknesses between magnetic reversals. Thicknesses were later verified with adjacent stratigraphic logs (Huerta, 2007), and finally plotted against magnetic reversal ages (Table 2). Some restrictions to the SR calculation are that: (i) sedimentation rates are inferred for intervals bounded by polarity reversals, and therefore represent average rates, and (ii) for short intervals the age uncertainty associated to the chron boundaries may lead to significant errors in the inferred SR. This allowed the assessment of SR for all the depositional systems in the monocline. Fluvial system is best represented in the Zárabes transect, mudflats and saline mudflats in the Colmenares transect, and lacustrine-palustrine systems in the Castillejos transect.

\section{4.-RESULTS}

\subsection{Large-scale architecture}

The Gómara monocline (Fig. 1) accommodates up to $2500 \mathrm{~m}$ of sediments comprising Depositional Sequences A1 to A3. The main large-scale architectural elements (LAE) defined are: i) Ribbon-shaped channel fills with low interconnectivity (Fig. 3A); ii) Sheet-like channel fills with high interconnectivity (Fig. 3B); iii) Palustrine/lacustrine Limestone units (Fig 3C and D); iv) Mudstone and evaporitic mudstone units (Fig. 3E); and v) stacked calcretes (Fig. 3F). These LAE pass gradually, vertically and laterally, from one into another. Frequent transitions from ribbon-shaped channel fills with low 
interconnectivity to sheet-like channel fills with high interconnectivity occur gradually by means of intermediate stacking patterns.

i) Ribbon-shaped channel fills with low interconnectivity.

This LAE is constituted by sandy ribbon-shaped channel fills and red mudstones, with a density of the channel bodies lower than $10 \%$ (Table 1; Fig. 4). It is most common in A2, especially in the middle of the sequence, and during A4 (Fig. 2). The channel and channel belt fills never exceed $50 \mathrm{~m}$ wide, being their common thickness around $2 \mathrm{~m}$ (Fig. 4A). The width/thickness (w/t) ratios typically range from 3:1 to $15: 1$, although in A4 some channel fills are vertically stacked (multi-storey) forming bodies with $1: 3 \mathrm{w} / \mathrm{t}$ ratios. These channels are isolated within red mudstones. Middle-scale and simple architectural members are described in Huerta (2007); Huerta et al. (2011).

ii) Sheet-like channel fills with high interconnectivity.

It is constituted by sheet-like conglomerate and sandstone channel fills and red mudstones. Occasionally, calcrete beds are intercalated within the mudstones. The density of the channels is high and ranges from the $20 \%$ to $52 \%$ (Table 2; Fig. 4). It is most frequent in the upper part of $A 3$, where channels are thicker, and wider (Fig. 4B). The channel and channel belts are wider than $500 \mathrm{~m}$, some exceeding $3000 \mathrm{~m}$. Common thickness is around $5 \mathrm{~m}$, although thicker conglomerate beds $(15-35 \mathrm{~m})$ are recorded in the upper part of $\mathrm{A} 3 \mathrm{~W} / \mathrm{W}$ ratios are higher than 100 and there are no evidences of vertical and lateral accretion. These channels and channel belts are dominated by conglomerates, which in the upper part of A3 contain clasts that can reach up to $70 \mathrm{~cm}$. Laterally to these channel fills calcretes are common. Middle-scale and simple architectural members are described in Huerta (2007); Huerta et al. (2011).

iii) Palustrine/lacustrine Limestones.

This unit consist of limestones, dolostones and marls which contain limnic fossils like gastropods, ostracods and charophytes. Reptile and mammal fossils have been occasionally found associated to these units. Carbonate facies have the classical exposition features defined in palustrine deposits, similar to those described by Alonso-Zarza et al. (1992); Armenteros et al. (1997); Huerta \& Armenteros (2005); Alonso-Zarza et al. (2006). Calcretes and dolocretes are common in the transitional areas between the limestone and the clastic units (Huerta \& Armenteros, 2004). The thickness of the palustrine/lacustrine limestones is about $200 \mathrm{~m}$ although it can reach a total thickness of $450 \mathrm{~m}$ (Deza Fm.) These units are preferentially found in A1/A2 boundary and in A2 (Fig. 2) and occurs in areas close to the basin margin, passing towards distal positions into an evaporitic mudflat. Simple elements and facies of the palustrine/lacustrine units are described in Huerta \& Armenteros (2004); Armenteros et al. (2006).

iv) Mudstones and evaporitic mudstones.

This unit consist of mudstones and mudstones with interstitial gypsum intercalated with tabular fine-sandstone beds and gypcretes (gypsum crusts). Sandstone channel fills are rare. It crops out in A2 and A3 in the southeastern part of the Gómara monocline and passes laterally into palustrine/lacustrine limestone units and ribbon- 
shaped channel fills with low interconnectivity. Simple elements and facies of this LAE are described in Huerta et al. (2010) which also describes the playa-lake system containing these deposits.

v) Stacked calcretes

This unit is constituted by several metre-scale calcrete profiles stacked vertically. The calcretes ranges from nodular or prismatic at the base to massive at the top. The massive top of a profile is overlapped by the nodular or prismatic horizon of the next profile. In some cases, the superposition of the calcrete profiles blurs the nodular or prismatic structure. In other cases the calcretes are separated by powdery carbonate or by red mudstones. The calcretes are constituted by a microsparitic mosaic with disperse quartz grains and show oxide staining patches and mudstone relics which become smaller towards the upper parts of the profile. This LAE occurs mainly in A3, laterally to the sheet-like channel fills with high interconnectivity. The calcretes and stacked calcretes related to the connection between palustrine/lacustrine units and the clastic units (A1/A2) are similar to those described here but the latter can pass upwards into dolocretes and palustrine/lacustrine limestones (Huerta \& Armenteros, 2004). The textural and structural features of the stacked calcretes are described in Huerta (2007) and Huerta et al. (2011).

\subsection{Sedimentology}

Previous sedimentological analysis of simple and medium architectural elements present in the $\mathrm{i}, \mathrm{ii}$, and $\mathrm{v}$ LAEs, interpret these deposits as parts of a distributive fluvial system with carbonate soils in distal floodplains (Huerta, 2007; Huerta et al., 2011). Ribbon-shaped channels have been interpreted as low sinuosity channels with minor lateral movement some of them showing anastomosis. Sheet-like channels have been interpreted as lateral-stacked channel belts with great mobility across the floodplain and a braided channel pattern. The stacked calcretes are interpreted as distal flooplain areas with important pedogenesis favoured by the low sediment accumulation (Huerta, 2007; Huerta et al., 2011). The LAEs identified in the vertical stacking pattern of fluvial system were laterally related, being the sheet-like channels with high interconnection upstream sections of the ribbon-shaped channels with low interconnection.

The mudstones and evaporitic mudstones have been interpreted as dry mudflats dominated by gypsum precipitation which passed southwards into saline mudflats and constituted a playa-lake system lateral to the main fluvial system (Huerta, 2007; Huerta et al., 2010).

The dry mudflat passes laterally into limestones and marls with gastropods, ostracods and charophytes. Some beds show exposure features, gypsum pseudomorphs and silica nodules. These carbonates have been interpreted as carbonate precipitating lakes or ponds with low gradient margins which connects with the clastic systems through carbonate soil fringes (calcretes/dolocretes) (Huerta, 2007). 
Alluvial fan sediments fringing the northern margin of the basin are not described here because they are not represented in the Gómara monocline. Only distal alluvial deposits are recorded in A1 (Miñana section).

\subsection{Magnetostratigraphic results}

Orange to reddish mudstones yielded unblocking temperatures circa $650^{\circ} \mathrm{C}$, suggesting that hematite is the principal magnetic carrier. Carbonate rocks yielded unblocking temperatures in general below $600^{\circ} \mathrm{C}$, suggesting that magnetite is more dominant in these lithologies. Most of the samples showed a low-temperature component, which is removed after $250^{\circ} \mathrm{C}$. The direction of this component in geographic coordinates usually parallels the drilling direction (Fig. 5a, sample MZ236), most likely related to recent viscous acquisition. A high temperature Characteristic Remanent Magnetisation (ChRM) ranging from $350^{\circ}$ to the maximum unblocking temperature is found in most of samples and yields both normal and reversed polarity directions. ChRM components were determined after inspection of Zijderveld plots in 234 samples (86.9\% of total), and directions were calculated by means of principal component analysis (Kirschvink, 1980) (Fig. 5a).

The stereographic plot of paleomagnetic data in geographic coordinates shows a distribution of normal and reversed polarity directions with low average inclinations (Fig. 5b). Tilt correction for the southwestwards dip of beds yielded steeper mean inclination values, which are more coherent with the Paleogene Iberian plate paleolatitude (Rosenbaum et al., 2002). Antipodality of the mean normal and reversed direction was not achieved, and low inclination values of the reverse samples may be related to partial overlap with a downwards-dipping low temperature secondary component (Fig.5). Westwards deviation of both normal and reverse mean directions could also be related to a partial overlap with drill-induced viscous magnetization. We interpret the low values of the precision parameter $(k)$ as caused by this overlap with secondary components (Fig.5).

The paleolatitude of the Virtual Geomagnetic Pole (VGP) was calculated at a sample level and plotted against thickness in order to establish a Local Magnetic Polarity Stratigraphy (LMPS, Fig. 6). Positive paleolatitudes were computed as normal polarities, while negative ones were interpreted as reversed polarities. Normal and reversed magnetozones were defined by at least two adjacent samples of the same polarity. Single-site reversals are depicted as half bar magnetozones in the LMPS plot, and are not considered for magnetostratigraphic correlation purposes. Correlation of the LMPS with the Global Polarity Time Scale (GPTS) was firstly based on biochronological data from the Mazaterón and Deza fossil mammal localities (Badiola et al., 2009), which suggest upper Eocene age. Guided by these constraints, a best correlation of the LMPS to the GPTS 2012 (Gradstein et al., 2012) was obtained by linking the very long reversed magnetozone R8 (Fig. 7) with chron C12R, the characteristic long reversed chron of the early Oligocene. A remarkable positive correlation results for most of the polarity sequence (Fig. 7). Solely the correlation of the normal magnetozone N3 presented some uncertainties. The proposed correlation of N3 with chron C19n yields significantly lower sedimentation rates than average. However, a significant lithology contrast takes place during this interval, with 
occurrence of calcretes indicating pedogenetic processes and environments with low sediment supply. This correlation is also supported by high-resolution magnetostratigraphic studies (Edgar et al., 2010) that find a new normal event within chron $\mathrm{C} 18 \mathrm{r}$ which would correlate with the short normal magnetozone within R3 in the Mazaterón Formation (Fig. 7).

\subsection{Age of Depositional Sequences and biostratigraphic calibration}

The most remarkable pattern shown by the isochrons map (Fig. 8) was the thicknesses variations, showing a wedging towards the East. This wedging is associated with an eastern gradual reduction of clastic sedimentation. In addition, the map reveals that variable widths between isochrones can be significant between adjacent areas, and that this relationship may change throughout time. The map also provides information for dating the depositional sequences boundaries across the basin, and the fossil sites located within the sequences.

The magnetostratigraphic study presented here provides a robust temporal framework for the Depositional Sequences of the Almazán Basin (Fig. 7). Depositional Sequence A1 is found to encompass from chron C21n to C18r, lasting ca. 5 Myr (Fig. 7). Depositional Sequence A2 encompasses from chron C18r to chron C13r, with duration of 5.8 Myr, and including most of the Bartonian and Priabonian Stages. Depositional Sequence A3 lasts 6.6 Myr, from chron $\mathrm{C} 13 \mathrm{r}$ to chron C9n, comprising the end of Priabonian, Rupelian and part of the Chattian. The Eocene/Oligocene boundary is placed near the base of A3 (Fig. 7). Magnetostratigraphic data are not available for Depositional Sequence A4 because this unit remains buried in the Gómara monocline, and ages can only be interpolated by means of seismic profiles.

The Mazaterón mammal fossil locality (MP 15-16, Cuesta \& Jiménez, 1994), in the lower part of the Mazaterón Formation (Fig. 7), correlates to chron C18r (Lower Bartonian), in agreement with previous biochronological interpretations (Cuesta \& Jiménez, 1994). The isochrons map allows dating the mammal fossil locality of Deza 2 (MP 17b, Badiola et al., 2009), yielding a correlation with Chron C15r, at midPriabonian (Fig. 8).

\subsection{Sedimentation Rates}

In order to assess the variabilitiy of SR both in time and space, the combined isochron map and bedding orientation data were used for calculation of SR along the different sections within the Gómara monocline. The results are shown in Fig. 9, where SR data is provided for every time-slice given by magnetostratigraphic reversals.

The general trend of SR shows pronounced shifts which are coincident with sequence boundaries. Both the A1/A2 and the A2/A3 boundaries are marked by increases of SR. Lateral changes in SR are associated to gradual changes of the depositional systems, which can be tentatively ordered from higher to lower SR. Although some exceptions exist, higher SR occur in fluvial systems, and gradually decrease in mudflat to lacustrine and finally palustrine settings with aerial exposition features. The principal exceptions 
occur in the mudflats or lacustrine systems which may present higher rates than certain fluvial intervals.

Within the fluvial system, highest SR are related to more isolated ribbon-like channels, while lowest SR are related to intervals of more amalgamated and wider channels. Ribbon-like channels develop when rates are above $25 \mathrm{~cm} / \mathrm{kyr}$, and amalgamated sheets occur when rates are below $12 \mathrm{~cm} / \mathrm{kyr}$. Between these values mixed architectures develop. Adjacent to the fluvial system, the mudflats yield SR which increase with the mud proportion and typically fluctuate between 14 to $23 \mathrm{~cm} / \mathrm{kyr}$. Finally, lacustrine systems lacking features indicating aerial exposure yield SR close to 9 $\mathrm{cm} / \mathrm{kyr}$, whereas the intervals dominated by calcrete accumulation record $3 \mathrm{~cm} / \mathrm{kyr}$. This indicates that net calcrete accumulation is below $3 \mathrm{~cm} / \mathrm{kyr}$ because the averaged intervals include other deposits apart from calcretes.

\section{5.-DISCUSSION}

\subsection{Basin fill and tectonic history}

\section{Depositional sequence A1}

Deposition in $\mathrm{A} 1$ begins as accommodation is created due to the Cameros thrust emplacement. The sedimentation grades upwards from distal alluvial to a calcrete fringe and palustrine-lacustrine environments. The average SR in the Miñana section (Figs. 8 and 9) show a change from 4.7 to $6.3 \mathrm{~cm} / \mathrm{kyr}$ in the alluvial deposits. A decrease to $3 \mathrm{~cm} / \mathrm{kyr}$ is related to the occurrence of stacked calcretes and palustrine/lacustrine limestones representing the carbonate soil fringe in the connection between the distal alluvial and the carbonate precipitating lake/pond. The increase in the SR recorded in the carbonates from Miñana section $(13.5 \mathrm{~cm} / \mathrm{kyr})$ is related to an increase in the palustrine/lacustrine facies at the upper part of $A 1$. This is interpreted as the beginning of a period with increasing AS which consolidates during A2.

Laterally, towards the Zárabes section (Fig. 8), the palustrine and lacustrine facies pass into fluvial deposits with wide and lateral amalgamated channels. SR of the fluvial deposits show an average of $7.4 \mathrm{~cm} / \mathrm{kyr}$. Similar SR values in the Zárabes and Miñana sections suggest that AS in the fluvial system is similar to the laterally related palustrine/lacustrine environments, but the sedimentary supply in the fluvial system hinders the expansion of the lake.

The beginning in AS creation around A1/A2 boundary and the increase in SS recorded by the development of the Gómara fluvial sytem is likely linked to an increase of the uplift in the Cameros Massif, which underwent maximum uplift rates at around $40 \mathrm{Ma}$ as indicated by fission track data (Del Rio et al., 2009). The uplift was transferred to the Almazán Basin by the activity of the Cameros thrust and, principally, by the inception of the South Cameros Thrust (SCT), and La Alameda Thrust (ATT; Fig. 10; Fig. 1 for location).

\section{Depositional sequence A2}


The sedimentation in $\mathrm{A} 2$ shows a broadening of the deposition areas towards the South and East (Fig. 10). The development of SCT and ATT provided additional accommodation space and an increase of sediment supply. The fluvial systems (Zárabes area) reflect an increase of SR to $15.5 \mathrm{~cm} / \mathrm{kyr}$, whereas the lacustrine environments of the Miñana section gradually shifted to fluvial deposits with rates slightly lower than in Zárabes (Fig. 9). In mid A2, the area experiencing more accommodation was Miñana instead of Zárabes. This is reflected in both sedimentation rates and in the Large-scale architectural pattern. The Miñana section show a sharp SR increase up to $40.1 \mathrm{~cm} / \mathrm{kyr}$ and ribbon-shaped channels with low interconnection. Contrastingly, the Zárabes section yields SR of $8.1 \mathrm{~cm} / \mathrm{kyr}$, at this interval characterized by a higher channel density and width.

Towards the SE the fluvial deposits pass into a dry mudflat formed by mudstones and evaporitic mudstones (Colmenares section). In the mudflat SR were slightly lower than in the fluvial system, suggesting that the change in the architectural pattern, with the absence of channel fills, is driven by a lateral reduction in clastic supply. Further east, palustrine/lacustrine limestone units (Deza deposits) reveal a extreme reduction in sediment supply allowing the development of lakes and ponds (Huerta et al., 2011) that are filled by bio-chemical precipitation (SR of $9 \mathrm{~cm} / \mathrm{kyr}$, Castillejos section). The overall decrease of the sediment supply towards the East occurred during $A 2$, in synchrony with fold growth in the Aragonian branch. Relief generation in this basinal domain controlled the main fluvial transfer system, and sheltered the eastern sectors from receiving significant clastic contributions. Towards the top of $A 2$, a general reduction in accommodation is deduced from the decreasing SR in all the sections (Fig.9). This trend caused channel amalgamation in fluvial units and calcrete occurrence in their lateral mudflat deposits.

\section{Depositional sequence $\mathbf{A} 3$}

The A2/A3 boundary correlates with the activity of existing and newly formed tectonic structures (Fig. 10), giving rise to unconformities at the basin margins. During A3 the Gómara monocline was active, generating large AS in the lower limb and reducing AS in the upper limb. SR strongly responded to these changes, increasing to $45.6 \mathrm{~cm} / \mathrm{kyr}$ in the Zárabes section, and $27.5 \mathrm{~cm} / \mathrm{kyr}$ in the Miñana section. This stage is marked by ribbon-shaped channel fills with low interconnection in the Zárabes section that laterally became wider and more amalgamated towards the Miñana section. Their lateral equivalent mudflat sediments yield lower SR values $(15.5 \mathrm{~cm} / \mathrm{kyr})$. The southeastwards decrease in SR is interpreted as driven by accommodation changes related to the position relative to the monocline limbs, the Zárabes section closer to the lower limb, and the Miñana and Colmenares sections closer to the upper limb. Neither the sediment supply pattern nor the distribution of the paleocurrents shows any significant change during this period.

A meter-thick fossil-rich calcrete yields interbeded within the A3 fluvial sequence in the Miñana section (near the Mazaterón village, Fig 2). The occurrence of this layer could record a decrease in sediment supply following the ideas of Carrol \& Bohacs (1999); Bohacs et al. (2000); Huerta et al. (2011). Since magnetostratigraphic correlation brings this bed at near the Eocene-Oligocene boundary, it is plausible that it represents a transient climatically-forced reduction of the sediment input. We note, 
however, that long-term architectural trends remain, with no sights of irreversible changes related to the transition into the icehouse world.

Towards the upper part of $A 3$, a significant reduction in SR is observed in all the sections (Fig.10). SR gradually decrease in the Zárabes section from values around 20 $\mathrm{cm} / \mathrm{kyr}$ to below $10 \mathrm{~cm} / \mathrm{kyr}$ (Fig. 9). Same trend, but delayed with respect to Zárabes, is observed in the Miñana section, decreasing from 20 to $10 \mathrm{~cm} / \mathrm{kyr}$. The reduction is SR is associated to the occurrence of the sheet-like channel fills with high interconnection. This is interpreted as a reduction in AS produced by the uplift of the Gómara monocline in its upper limb. The reduction in AS favours the lateral expansion of the fluvial system which is recorded in the Colmenares section and the migration of the fluvial depocentre southwards towards the basin centre (See Fig.1B).

\section{Depositional sequence A4}

Previous studies (Huerta 2007; Huerta et al., 2011) showed that A4 (Chattian to Miocene) records the uplift and erosion of the northern domain of the basin, and coarse alluvial fan deposits with internal unconformities occur at the southeast domain (Deza-Embid area). A4 articulates in the Gómara monocline displaying syntectonic unconformities and becoming thicker southwards. This stratal pattern, the occurrence of ribbon-shaped channel fills with low interconnection, and the unroofing of the northern domain suggest that although sedimentation rates have not been calculated for this depositional sequence, both AS and SS were relatively high.

\subsection{Accommodation, Sediment supply, and Large-scale architecture.}

Sedimentation rates reflect the accommodation space for a specific site and time interval, following Muto and Steel (2000). The SR calculated in the Gómara monocline (Almazán Basin) help us assessing the relationship between the large-scale sedimentary architecture and the accommodation space and sediment supply.

As seen above, sheet-like channel fills with high interconnectivity LAE occur at times of lower accommodation space (see upper part of the A3 with SR around or below 10 $\mathrm{cm} / \mathrm{kyr}$ ) than the ribbon-shaped channel fills with low interconnectivity (see A2 with SR around $30-40 \mathrm{~cm} / \mathrm{kyr}$ ) (Fig. 9). In this scenario, low SR reflect the low aggradation of the floodplains favouring lateral mobility and an increase of channel density, while high SR reflect an important aggradation of the floodplain which favoured avulsion and predominance of isolated channels (Bryant, 1995). This is consistent with data from experimental models which indicate that the higher SR are recorded in floodplains while channels only act as conduits for sediment bypass (Sheets et al., 2002). It is important to note that the two LAE discussed above develop in high sediment supply conditions as revealed by the clast size and the sedimentary system arrangement.

The distal and lateral reductions in SS are evidenced by the grain-size finning trend from the fluvial system to the mudflats and lacustrine environments. The AS in the palustrine/lacustrine limestone units ( $S R$ around $9 \mathrm{~cm} / \mathrm{ky}$ ) is lower than in the correlative mudflats mudstones (SR around $15-20 \mathrm{~cm} / \mathrm{kyr}$ ), and these lower than in the 
correlative ribbon-shaped channel fills with low interconnection. This lateral/distal reduction of AS is associated to a reduction in the SS.

Stacked calcretes reflect the lowest AS (SR around $3 \mathrm{~cm} / \mathrm{kyr}$ ) and low sediment supply as deduced from their location in the distal floodplain, distal alluvial and dry mudflats equivalent to sheet-like channels with high interconnections. This is in agreement with the occurrence of calcretes in low deposition settings (Tandon et al, 1998), sheltered (Armenteros \& Huerta, 2006) or uplifting regions (Alonso-Zarza et al., 1999).

The study of ancient fluvial systems shows marked differences in sedimentation rates, these ranging over two orders of magnitude. When fluvial systems are analysed in the long term (SRS 9-10 of Miall, 2014), most of the data fall within the range given in the compilation work of Colombera et al., (2015), with sedimentation rates between 55-60 $\mathrm{cm} / \mathrm{kyr}$ and $1 \mathrm{~cm} / \mathrm{kyr}$. For example, SR for the Siwalik sections in Pakistan average 12 $\mathrm{cm} / \mathrm{kyr}$ (Johnson et al., 1988) and the fluvial deposits of the Junggar Basin (China) around $24.5 \mathrm{~cm} / \mathrm{kyr}$ (Ji et al., 2008). The overbank and paleosol alternation of the Bighorn Basin (Wyoming) show that average rates are in the range between $40 \mathrm{~cm} / \mathrm{kyr}$ and $28.8 \mathrm{~cm} / \mathrm{kyr}$ (Abels et al., 2013). Similarly, sedimentation in mudflat deposits yields values that easily overcome one order of magnitude. Abels et al., (2011), in the Tibetan Plateau, show SR of about $4.6 \mathrm{~cm} / \mathrm{kyr}$ in mudflat environments, down to $2.1 \mathrm{~cm} / \mathrm{kyr}$ in gypsiferous mudflats. In the Calatayud-Daroca basin (central Spain) mudflat-dominated deposits record SR rates of about $5 \mathrm{~cm} / \mathrm{kyr}$ (Abdul-Aziz et al., 2000). In lacustrine settings SR vary over a narrower range, from $10 \mathrm{~cm} / \mathrm{kyr}$ in the Green River Basin (Smith et al., 2008), to $6-10 \mathrm{~cm} / \mathrm{kyr}$ in the Oligocene fresh water lacustrine deposits of the Ebro Basin (Valero et al., 2014), and $6.5 \mathrm{~cm} / \mathrm{kyr}$ in the Junggar Basin (Ji et al., 2008). Variations in lacustrine settings depend on the local subsidence, source area, paleoproductivity and the over- or underfilling state of the basin (Carroll \& Bohacs, 1999). Finally, the calcretes are suggested to form when pedogenesis overcome sedimentation rates (Machette, 1985) and Daniels et al., (2003) stated that $0.5 \mathrm{~cm} / \mathrm{kyr}$ is the threshold rate of pedogenic assimilation. The rate of local subsidence and the type of calcretes may increase this range as fine interbedding with other deposits is common. SR for calcretes are thought to be in a range between less than $3 \mathrm{~cm} / \mathrm{kyr}$ and punctual negative sedimentation.

The balance between AS and SS represents the response of the basin to external forcing. Size, slope, tectonic evolution and the nature of the source areas are specific of each basin. Thus it may be inaccurate to extrapolate absolute rates to other basins. However, the relative vertical and lateral variations and their relationship to the balance between accommodation and sediment supply may be shared with other sedimentary records.

\subsection{Climate and tectonics}

Lateral changes in accommodation space and sediment supply in the Almazán Basin are mainly driven by the tectonic uplift of the Cameros Massif and the Iberian Chain. This is supported by the sequence stratigraphy of the basin, and the documented relationship between sedimentary unconformities and tectonic structures. Palaeocurrents, clast composition and clay mineralogy analyses were carried in order to identify the role of tectonics during basin filling (Huerta, 2007). Thrusting and 
folding along the margins provided the basin with sediments and the regional flexural subsidence that supports long-term accommodation. On the other hand, intrabasinal thrusting modified the sediment routing system and contributed to the localized generation or destruction of accommodation space.

Despite the buffering of the upstream signal in large to medium drainage systems (Castelltort \& Van Der Driessche, 2003), it has been shown that fluvial deposits can record climatic oscillations (Abels et al., 2013). Recent studies in the Teruel Basin suggest that the superimposition of climate and tectonics exerts an important control on lacustrine sedimentation an in the expansion and retraction of the lake deposits (Alonso-Zarza et al., 2012; Ezquerro et al., 2014). In other basins of the Iberian Chain, the main sedimentary ruptures are not found to correlate with climate change (López Martínez et al., 1987; Calvo et al., 1993; Muñoz-Jiménez \& Casas-Sainz, 1997). Added to this complexity, it has been shown that the autogenic response of the sedimentary systems can produce organized stratal patterns with no need of external control (Hajek et al., 2012).

In the Almazán basin, well defined large-scale architectural trends occur at basin scale, thus indicating external forcing. No evidence of climate forcing, such as recognition of orbital cyclicity or correlation with global events, is found at this scale. The singularity of a calcrete bed at near the Eocene-Oligocene boundary could represent a climatically-driven transient decrease in the sediment input, but no remarkable shift in the overall sedimentary stacking pattern can be associated to this global scale climate transition. Thus, the occurrence of long-term orbital cycles in the Paleogene fluvial record of the Almazán basin remains not demonstrated. Further research focussed on the evaporitic mudflats and lacustrine/palustrine limestones could provide useful information on this issue.

\section{6.-CONCLUSIONS}

The magnetostratigraphy for the Paleogene continental record of the Almazán Basin allows filling a gap of the Cenozoic chronostratigraphy of the Spanish basins. This work permits settling ages of the fossil mammal sites and the depositional sequence boundaries of the basin. In addition, the new ages provide the resolution needed to quantify of sedimentary rates throughout the Gómara Monocline. The combined evolution of depositional sequences, the architectural shifts, and the variations of sedimentation rates are interpreted in terms of accommodation and sediment supply changes.

The magnetostratigraphic results reveal that the first depositional sequence A1 started in mid-Lutetian times (chron C21n) in relation to the emplacement of the Cameros Main thrust. The development of the South Cameros Thrust started in early Bartonian (chron C18r), synchronously to deposition of A2. Close to the Eocene/Oligocene transition sedimentation of A3 starts, coeval to the growth of the Gómara, Almazán and the Arcos monoclines, and associated structures, producing differential changes in accommodation space. Since middle Chattian (chron C9n.1n), A4 records the increase in the tectonic activity. The uplift of the Gómara monocline produced the erosion of 
the northern domain and created growth strata that articulated in the Gómara monocline.

Relative changes in SR show a correspondence with the large-scale sedimentary architecture, and relative changes in the AS/SS ratio reveal useful for stratal pattern prediction. In areas with high sediment supply, higher SR $(30-40 \mathrm{~cm} / \mathrm{kyr})$ are related to ribbon-shaped isolated channel fills (channel density $<10 \%$ ) and predominance of floodplain fine grained deposits. On the other hand, lower SR $(<10 \mathrm{~cm} / \mathrm{kyr})$ correspond to laterally extensive sheet-like interconnected channel fills (channel density from 20 to $50 \%$ ) and an increase in the average grain size.

In basin sectors with low sediment input, the predominance of fine sediments, mudstones and evaporitic mudstones reveals a slight decrease in sedimentation rates (SR around $15-20 \mathrm{~cm} / \mathrm{kyr}$ ) with respect to the areas with high sediment supply (fluvial system). Palustrine/lacustrine limestone units occur in areas of very low sediment input and low sedimentation rates (SR around $9 \mathrm{~cm} / \mathrm{ky}$ ) which are reflecting the carbonate production. Stacked calcrete profiles develop in areas with low sediment supply and very low sedimentation rates (SR around $3 \mathrm{~cm} / \mathrm{kyr}$ ) related to distal alluvial or distal floodplain areas.

\section{Acknowledgments}

This research was funded by the Spanish projects COFORSED (CGL2010-17479) and SEROS (CGL2014-55900-P), and the Research Group of "Geodinàmica i Anàlisi de Conques" (2014SGR467). LV acknowledges the University of Barcelona for financial support (APIF-UB). Thanks to Cor Langereis, Tom Mullender and Maxim Krasnoperov from the Fort Hoofdijk Paleomagnetic Laboratory (Utrecht University), and to the Barcelona Paleomagnetic Laboratory (CCiTUB-ICTJA CSIC). We are very grateful to the Editor Sébastien Castelltort, and to Liz Hajek, Ana Alonso-Zarza and an anonymous reviewer for their valuable comments on the manuscript. This is a contribution to the ESF Research Networking Programme EARTHTIME-EU (08-RNP-017) and the Geomodels Institute (Universitat de Barcelona).

\section{References}

ABDUL-AZIZ, H., HILGEN, F., KRIJGSMAN, W., SANZ \& E., CALVO, J.P., (2000) Astronomical forcing of sedimentary cycles in the middle to late Miocene continental Calatayud Basin (NE Spain). Earth Planet. Sci. Lett., 177, 9-22

ABELS, H. A., KRAUS, M. J., GINGERICH, P. D. (2013) Precession-scale cyclicity in the fluvial lower Eocene Willwood Formation of the Bighorn Basin, Wyoming (USA). Sedimentology, 60, 1467-1483. doi: 10.1111/sed.12039

ABELS, H. A., DUPONT-NIVET, G., XIAO, G. Q., BOSBOOM, R., \& KRIJGSMAN, W. (2011) Stepwise change of Asian interior climate preceeding the Eocene-Oligocene Transition (EOT). Paleogeogr. Paleoclimatol., Palaeocol., 299, 399-412

ALLEN, J.R.L. (1978) Studies in fluviatile sedimentation: An exploratory quantitative model for the architecture of avulsion-controlled alluvial suites: Sediment. Geol., 21, p. 129-147, doi:10.1016/0037-0738(78)90002-7. 
ALONSO-ZARZA, A.M., CALVO, J.P. \& GARCÍA DEL CURA, M.A. (1992). Palustrine sedimentation and associated features -grainification and pseudo-microkarst- in the Middle Miocene (Intermediate Unit) of the Madrid Basin, Spain. Sediment Geol, 76, 43-61.

ALONSO-ZARZA, A.M., SOPEÑA, A. AND SANCHEZ-MOYA, Y., (1999). Contrasting palaeosol development in two different tectonic settings: the Upper Buntsandstein of the Western Iberian Ranges, Central Spain. Terra Nova, 11, 23-29.

ALONSO-ZARZA, A.M., (2003). Palaeoenvironmental significance of palustrine carbonates and calcretes in the geological record. Earth-Sci. Rev., 60, 261-298.

ALONSO-ZARZA, A.M., DORADO-VALIÑO, M., VALDEOLMILLOS-RODRÍGUEZ, A. \& RUIZ-ZAPATA, M.B. (2006). A recent analogue for palustrine carbonate environments: The Quaternary deposits of Las Tablas de Daimiel wetlands, Ciudad Real, Spain. In: Paleoenvironmental record and applications of calcretes and palustrine carbonates (Ed. by A.M. Alonso-Zarza \& L.H. Tanner), Geol. Soc. London, Spec. Publ, 416, pp. 153-168.

ALONSO-ZARZA, A., MELÉNDEZ, A., MARTíN-GARCÍA, R., HERRERO, M.J., \& MARTíN-PÉREZ, A., (2012) Discriminating between tectonism and climate signatures in palustrine deposits: Lessons from the Miocene of the Teruel Graben, NE Spain. Earth-Sci. Rev., 113, 141-160

ARMENTEROS, I., DALEY, B. \& GARCIA, E. (1997). Lacustrine and palustrine facies in the Bembridge Limestone (late Eocene, Hampshire Basin) of the Isle of Wight, southern England. Palaeogeogr Palaeoclimatol Palaeoecol, 128, 111-132.

ARMENTEROS, I., BUSTILLO, M.A. \& HUERTA, P. (2006). Ciclos climáticos en un sistema lacustre marginal perenne carbonatado-evaporítico. Formación Deza, Eoceno superior, cuenca de Almazán. Geo-temas, 9, 25-30.

ARMENTEROS, I. \& HUERTA, P., (2006). The role of clastic sediment influx in the formation of calcrete and palustrine facies: A response to paleographic and climatic conditions in the southeastern Tertiary Duero basin (northern Spain). Geol. Soc. Am. S. 416, 119132. doi:10.1130/2006.2416(08).

ARMITAGE, J.J., DULLER, R.A., WHITTAKER, A.C. \& ALLEN, P. (2011) Transformation of tectonic and climatic signals from source to sedimentary archive. Nat. Geosci., 1-5, DOI:10.1038/NGEO1087

BADIOLA, A., CHECA, L., CUESTA, M.A., QUER, R., HOOKER, J.J., ASTIBIA, H., NATURAL, T. \& MUSEUM, H., (2009). The role of new Iberian finds in understanding European Eocene mammalian paleobiogeography. Geol. Acta 7, 243-258. doi:10.1344/105.000000281.

Bohacs, K.M., Carroll, A.R., Nede, J.E. \& MANKIROWICZ, P.J. (2000) Lake-Basin Type, Source Potential and Hydrocarbon Character: An Integrated Sequence-StratigraphicGeochemical Framework. In: Lake Basins through Space and Time (Ed. by E. H. Gierlowski-Kordesch \& K. R. Kelts), Aapg Studies in Geology, 46, 3-33. American Association of Petroleum Geologists, Tulsa, Ok., U.S.A.

BRIDGE, J.S. \& LEEDER, M.R. (1979). A simulation model of alluvial stratigraphy. Sedimentology, 26, 617-644.

BRYANT, M., FALK, P. \& PAOLA, C. (1995). Experimental study of avulsion frequency and rate of deposition. Geology, 23, 365-368.

Calvo, J.P., DaAms, R., Morales, J., López Martínez, N., Agustí, J., Anadón, P., ARmenteros, l., Cabrera, L., Civis, J., Corrochano, A., Díaz Molina, M., Elizaga, E., Hoyos, M., MartínSuÁrez, E., Martínez, J., Moissenet, E., Muñoz, A. \& Pérez García, A. (1993) Up-to-Date Spanish Continental Neogene Synthesis and Paleoclimatic Interpretation. Revista de la Sociedad Geológica de España, 6, 29-40.

CARROLL, A.R. \& BoHACS, K.M. (1999) Stratigraphic Classification of Ancient Lakes: Balancing Tectonic and Climatic Controls. Geology, 27, 99-102.

CASAS-SAINZ, A.M. (1993). Oblique tectonic inversion and basement thrusting in the Cameros Massif (Northern Spain). Geodin. Acta, 6, 202-216. 
CASAS-SAINZ, A.M., CORTÉS-GARCÍA, A.L. \& MAESTRO-GONZÁLEZ, A., (2000). Intraplate deformation and basin formation during the Tertiary within the northern Iberian plate: origin and evolution of the Almazán basin. Tectonics, 19, 258-289.

CASAS-SAINZ, A.M., CORTÉS, A.L. \& MAESTRO, A. (2002). Sequential limb rotation and kinkband migration recorded by growth strata, Almazán Basin, North Spain. Sediment Geol, $146,25-45$.

CASAS, A.M. (1990). El frente Norte de la Sierra de Cameros: Estructuras cabalgantes y campo de esfuerzos. PhD Thesis, Universidad de Zaragoza, Zaragoza.

CASTELLTORT, S. \& VAN DER DRIESSCHE, J. (2003) How plausible are high-frequency sediment supply-driven cycles in the stratigraphic record? Sediment. Geol., 157, 3-13

CATUNEANU, O. \& ELANGO, H.N. (2001). Tectonic control on fluvial styles: The Balfour formation of the Karoo Basin, South Africa. Sediment Geol, 140, 291-313.

CATUNEANU, O. (2006). Principles of Sequence Stratigraphy. Elsevier, Amsterdam.

CATUNEANU, O., ABREU, V., BHATTACHARYA, J.P., BLUM, M.D.,DALRYMPLE, R.W, ERIKSSON,.G., FIELDING, C.R., FISHER,W.L., GALLOWAY, W.E., GIBLING, M.R., GILES, K.A., HOLBROOKL, J.M., JORDAN, R., KENDALL, C.G.ST.C., MACURDA, B., MARTINSEN, O.J., MIALL, A.D., NEAL, J.E., NUMMEDAL, D., POMAR, L., POSAMENTIER, H.W., PRATT, B.R., SARG, J.F.,SHANLEY, K.W., STEEL, R.J., STRASSER, A., TUCKER, M.E. \& WINKER, C. (2009) Towards the standardization of sequence stratigraphy. Earth-Science Reviews, 92, 1-33

COLOMBERA, L., MOUNTNEY, N. P., \& MCCAFFREY, W. D. (2015). A meta-study of relationships between fluvial channel-body stacking pattern and aggradation rate: Implications for sequence stratigraphy. Geology, 43(4), 283-286

CUESTA, M.A. \& JIMÉNEZ, E., (1994). Síntesis del Paleógeno del borde oriental de la cuenca de Almazán (Soria): Vertebrados de Mazaterón. Stud. Geol. Salmatic. XXIX, 157-170.

DANIELS, J. M. (2003) Floodplain aggradation and pedogenesis in a semiarid environment. Geomorphology, 56, 2252242

DEL RIO, P., BARBERO, L., \& STUART, F.M., (2009). Exhumation of the Sierra de Cameros (Iberian Range, Spain): constraints from low-temperature thermochronology. Geol. Soc. London, Spec. Publ. 324, 153-166. doi:10.1144/SP324.12

EDGAR, K.M., WILSON, P. A., SEXTON, P.F., GIBBS, S.J., ROBERTS, A. P. \& NORRIS, R.D., (2010). New biostratigraphic, magnetostratigraphic and isotopic insights into the Middle Eocene Climatic Optimum in low latitudes. Palaeogeogr. Palaeoclimatol. Palaeoecol. 297, 670-682. doi:10.1016/j.palaeo.2010.09.016.

Ezquerro, L., Luzón, A., NAVArRo, M., LieSA, C.L. \& Simón, J.L. (2014) Climatic Vs. Tectonic Signals in a Continental Extensional Basin (Teruel, Ne Spain) from Stable Isotope $\left(\delta^{18} \mathrm{O}\right)$ and Sequence Stratigraphical Evolution. Terra Nova, 26, 337-346.

FOIX, N., PAREDES, J.M. \& GIACOSA, R.E. (2013). Fluvial architecture variations linked to changes in accommodation space: Río Chico Formation (Late Paleocene), Golfo San Jorge basin, Argentina. Sediment Geol., 294, 342-355.

GUIMERÀ, J., ALONSO, A., \& MAS, R. (1995). Inversion of an Extensional Ramp Basin by a Neoformed thrust: The Cameros Basin (N Spain). In: Basin Inversion (Ed. by J.G. Buchanan \& P.G. Buchanan), Geological Society Special Publication, 88, 433-453.

GRADSTEIN, F.M., OGG, J.G., SCHMITZ, M. \& OGG, G., (2012). The Geologic Time Scale 2012. Elsevier, Cambridge University Press, Cambridge.

HAJek, E.A., Heller, P.L. \& SCHUR, E.L. (2012) Field Test of Autogenic Control on Alluvial Stratigraphy (Ferris Formation, Upper Cretaceous-Paleogene, Wyoming). Geological Society of America Bulletin, 124, 1898-1912.

HELLER, P.L. \& PAOLA, C. (1996). Downstream changes in alluvial architecture: an exploration of controls on channel-stacking patterns. J. Sediment. Res., 66, 297-306. 
HELLER, P.L., PAOLA, C., HWANG, I.-G., JOHN, B. \& STEEL, R.J. (2001). Geomorphology and sequence stratigraphy due to slow and rapid base-level changes in an experimental subsiding basin (XES 96-1). Am. Assoc. Petr. Geol. B., 85, 815-838.

HICKSON, T.A., SHEETS, B.A., PAOLA, C. \& KELBERER, M. (2005). Experimental test of tectonic controls on three-dimensional alluvial facies architecture. J. Sediment. Res., 75, 710722.

HILGEN, F.J., HINNOV, L.A., ABDUL AZIZ, H., ABELS, H.A., BATENBURG, S., BOSMANS, J.H.C., DE BOER, B., HÜSING, S.K., KUIPER, K.F., LOURENS, L.J., RIVERA, T., TUENTER, E., VAN DE WAL, R.S.W., WOTZLAW, J.-F., ZEEDEN, C. (2014). Stratigraphic continuity and fragmentary sedimentation: the success of cyclostratigraphy as part of integrated stratigraphy. In: Strata and Time: Probing the Gaps in Our Understanding (Ed. by D. G. Smith, R. J., Bailey, P. M, Burgess, \& A. J., Fraser) Geol. Soc. London Spec. Publ., 404. doi: $10.1144 / S P 404.12$

HUERTA, P. \& ARMENTEROS, I. (2004). Asociaciones de carbonatos continentales en el Eoceno de la Cuenca de Almazán. Geo-temas, 6, 75-78.

HUERTA, P. \& ARMENTEROS, I. (2005). Calcrete and palustrine assemblages on a distal alluvialfloodplain: A response to local subsidence (Miocene of the Duero basin, Spain). Sediment Geol, 177, 253-270.

HUERTA, P., ARMENTEROS, I., RECIO, C. \& BLANCO, J.A. (2010). Palaeogroundwater evolution in playa-lake environments. Sedimentary facies and stable isotope record (Palaeogene, Almazán basin, Spain). Palaeogeogr, Palaeoclimatol, Palaeoecol, 286, 135-148.

HUERTA, P., ARMENTEROS, I. \& SILVA, P.G. (2011). Large-scale architecture in non-marine basins: The response to the interplay between accommodation space and sediment supply. Sedimentology, 58, 1716-1736.

HUERTA, P. (2007). El Paleógeno de la cuenca de Almazán. Relleno de una cuenca piggyback. PhD Thesis, Universidad de Salamanca, Salamanca, Spain.

JI, J., LUO, P., WHITE, P., JIANG, H., GAO, L., DING, Z. (2008) Episodic uplift of the Tianshan Mountains sice the Late Oligocene constrained by magnetostratigraphy of the Jingou River section, in the southern margin of the Junggar Basin, China. J. Geophys Res., 113, B05102, doi:10.1029/2007JB005064

JOHNSON, N. M., SHEIKH, K. A., DAWSON-SAUNDERS, E., \& MCRAE, L. E. (1988). The use of magnetic-reversal time lines in stratigraphic analysis: A case study in measuring variability in sedimentation rates. In: New perspectives in basin analysis (Ed. Kleinspehn, K. L., \& Paola, C.), pp. 189-200. Springer-Verlag, New York.

KIM, G., ALLEMAN, L.Y. \& CHURCH, T.M. (2004). Accumulation records of radionuclides and trace metals in two contrasting Delaware salt marshes. Mar. Chem., 87, 87-96.

KIRSCHVINK, J.L. (1980). The least-squares line and plane and the analysis of palaeomagnetic data. Geophys. J. Int., 62, 699-718. doi:10.1111/j.1365-246X.1980.tb02601.x

LEGARRETA, L. \& ULIANA, M.A. (1998). Anatomy of hinterland depositional sequences: Upper Cretaceous fluvial strata, Neuquén basin, west-central Argentina. In: Relative role of Eustasy, Climate, Tectonism in Continental Rocks (Ed. K.W. Shanley \& P.J. McCabe). SEPM Spec. P., 59, 83-92. Society of Economic Paleontologists and Mineralogists, Tulsa, OK, USA.

López Martínez, N., Agustí, J., Cabrera, L., Calvo, J.P., Civis, J., Corrochano, A., DaAms, R., Díaz, M., elízaga, E., Hoyos, M., Martínez, J., Morales, J., Portero, J., Robles, F., SAntisteban, C. \& TORRES, T. (1987) Approach to the Spanish Continental Neogene Synthesis and Paleoclimatic Interpretation. Annales Instituti Geologici Publici Hungarici, 70, 383-391.

MACHETTE, M.N. (1985) Calcic soils of southwestern United States. In: Weide, D.L. (Ed.), Soil and Quaternary Geology of the Southwestern United States. Geol. S. Am. S., 203, pp. 1221 
MACKEY, S.D. \& BRIDGE, J.S. (1995). Three-dimensional model of alluvial stratigraphy: theory and application. J. Sediment. Res., B65, 7-31.

MIALL, A.D. (2014) Fluvial Depositional Systems. Springer, New York, USA

MICHAEL, N.A., WHITTAKER, A.C., CARTER, A. \& ALLEN, P.A. (2014). Volumetric budget and grain-size fractionation of a geological sediment routing system: Eocene Escanilla Formation, south-central Pyrenees. Geol. Soc. Am. Bull., 126, 585-599.

MITCHUM, R.M., JR., VAIL, P.R. \& THOMPSON, S., III. (1977). Seismic stratigraphy and global changes of sea level. Part 2: The depositional sequence as a basic unit for stratigraphic analysis. In: Seismic Stratigraphy; applications to Hydrocarbon Exploration (Ed. C.E. Payton), AAPG Mem., 26, 53-62. American Association of Petroleum Geologists, Tulsa, OK.

MUÑOZ-JIMÉNEZ, A. \& CASAS-SAINZ, A.M. (1997) The Rioja Trough (N Spain): Tectosedimentary Evolution of a Symmetric Foreland Basin. Basin Research, 9, 65-85.

MUTO, T., \& STEEL, R. J. (1997) Principles of regression and transgression: the nature of the interplay between accommodation and sediment supply. J. Sedimen. Res., 67, 9941000.

MUTO, T. \& STEEL, R.J., (2000) The accommodation concept in sequence stratigraphy: some dimensional problems and possible redefinition. Sediment. Geol., 130, 1-10.

NAVARRO VÁQUEZ, D. (1991). Mapa Geológico de España 1:50000, Hoja 350 (Soria), ITGE. Madrid.

PAOLA, C. \& MARTIN, J.M. (2012). Mass-balance effects in depositional systems. J. Sediment. Res., 82, 435-450.

POSAMENTIER, H.W. \& VAIL, P.R. (1988). Eustatic controls on clastic deposition. II: Sequence and systems tract models. In: Sea-Level Changes-An Integrated Approach (Ed. by C.K. Wilgus, B.S Hastings, C. St. C. Kendall, H.W. Posamentier, C.A. Ross \& J.C. Van Wagoner). SEPM, 42, pp. 125-154. OK, USA

ROSENBAUM, G., LISTER, G.S. \& DUBOZ, C., (2002). Relative motions of Africa, Iberia and Europe during Alpine orogeny. Tectonophysics 359, 117-129. doi:10.1016/S00401951(02)00442-0

SHANLEY, K.W. \& MCCABE, P.J. (1991). Predicting facies architecture through sequence stratigraphy -an example from the Kaiparowits Plateau, Utah. Geology, 19, 742-745.

SHANLEY, K.W. \& MCCABE, P.J. (1993). Alluvial architecture in a sequence stratigraphic framework: a case history from the Upper Cretaceous of southern Utah, USA. In: Quantitative Description and Modelling of Clastic Hydrocarbon Reservoirs and Outcrop Analogues (Ed. by S. Flint \& I.D. Bryant). Int. As. Sed., 15, pp. 21-56.

SHEETS, B.A., HICKSON, T.A. \& PAOLA, C. (2002). Assembling the stratigraphic record: depositional paterns and time-scales in an experimental alluvial basin. Basin Res., 14, 287-301.

STRONG, N., SHEETS, B.A., HICKSON, T.A. \& PAOLA, C. (2005). A mass-balance framework for quantifying downstream changes in fluvial architecture. In: Fluvial Sedimentology VII. (Ed. M.D. Blum, S.B. Marriott \& S. Leclair), Int. As. Sed., 35, pp. 243-253. Blackwell.

TANDON, S.K., ANDREWS, J.E., SOOD, A. \& MITTAL, S. (1998) Shrinkage and Sediment Supply Control on Multiple Calcrete Profile Development: A Case Study from the Maastrichtian of Central India. Sediment. Geol., 119, 25-45.

TÖRNQVIST, T.E. (1994) Middle and late Holocene avulsion history of the River Rhine (RhineMeuse delta, Netherlands). Geology, 22, 711-714.

VAIL, P.R. \& MITCHUM, R.M., JR. (1977). Seismic Stratigraphy and global changes of sea level. Part 1: Overview. In: Seismic Stratigraphy - Applications to Hydrocarbon Exploration, (Ed. by C.E. Payton). AAPG Mem., 26, 51-52. American Association of Petroleum Geologists, Tulsa, OK. 
VALERO, L., GARCÉS, M., CABRERA, L., COSTA, E., \& SÁEZ, A. (2014). 20 Myr of eccentricity paced lacustrine cycles in the Cenozoic Ebro Basin. Earth Planet. Sci. Lett., 408, 183193.

VAN WAGONER, J.C., POSAMENTIER, H.W., MITCHUM, R.M., JR., VAIL, P.R., SARG, J.F., LOUTIT, T.S. AND HARDENBOL, J. (1988). An overview of the fundamentals of sequence stratigraphy and key definitions. In: Sea-Level Changes-An Integrated Approach (Ed. by C.K. Wilgus, B.S Hastings, C. St. C. Kendall, H.W. Posamentier, C.A. Ross \& J.C. Van Wagoner). SEPM, 42, pp. 39-45. OK, USA.

WRIGHT, V.P. \& MARRIOTT, S.B. (1993). The sequence stratigraphy of fluvial depositional systems: the role of floodplain sediment storage. Sediment. Geol., 86, 203-210. 
Table 1

Channel density values for eight boxes of the Gómara Monocline. 4 in DS A2 and 4 in DS A3. The exact location of the Boxes can be found in a supplementary file (. $\mathrm{kmz})$

Table 2.

Sedimentation rates values for different intervals within the Gómara Monocline.

Figure 1

a) Tectonic map of the Northeastern domain of the Almazán basin, where the depositional sequences are shown, after Huerta et al., (2011). The main tectonic structures are also indicated. Squared in the center is indicated the location of Fig. 2. B) Cross section oriented SSE-NNW, which location is shown above at the left. The depositional sequences and the tectonic domains of the basin are indicated.

Figure 2

Detailed map of the lithostratigraphic formations cropping out along the Gómara monocline (see location in Fig. 1). In grey, the trace of fluvial channels is marked. Dark green line shows the magnetostratigraphic sampling track.

Figure 3

Field photographs of the main large-scale architectural elements identified in the Paleogene succession of the Almazán Basin. A) Low interconnected ribbon-shaped channel fills (Alparrache Formation). B) Highly interconnected sheet-like channel fills (Upper part of the Gómara Formation). C) and D) shallow water lacustrine carbonates of the Deza Formation, D) an almost complete view of the carbonate deposits (about $200 \mathrm{~m}$ ) is shown. E) Mudflat deposits of the Bordalba Formation (close to the Colmenares section). F) Stacked calcretes at the base of the Mazaterón Formation, which top is at the right of the picture.

Figure 4

Changes in the interconnectivity of channels due to variations in fluvial regime are recorded several times in the Gómara Formation. A) Example of low-density of fluvial channels areas, which mainly bear ribbon-like channel fills with low W/T ratios. B) High density of channels. Sheet-like channel fills, with high $W / T$ ratios. In this case, located in the top of $A 3, W / T$ ratios overcome 100.

Figure 5

A) Stepwise NRM thermal demagnetization (Zijderveld plots) of representative lithologies and normalized NRM and magnetic susceptibility changes upon heating from the Almazul and Mazaterón sections. MO: Initial NRM in $10^{-6} \mathrm{~A} / \mathrm{m}$. B) Stereographic projection of the ChRM directions before and after tectonic correction and their associated normal and reversed mean directions by means of Fisherian statistics. 
Figure 6

Local litho- and magnetostratigraphic composite section. From left to right, changes in declination, inclination and Virtual Geomagnetic Pole (VGP) paleolatitudes. The correlation between Almazul and Mazaterón sections was performed by means of magnetostratigraphy. Stable magnetozones were defined by at least two adjacent palaeomagnetic sites of the same polarity. Normal magnetozones are represented in black and reversed magnetozones are represented in white. Single site reversals are represented by half bar magnetozones

Figure 7.

Correlation between the local magnetostratigraphic section of Almazán to the GPTS (Gradstein et al., 2012), including the formations and the depositional sequences of the Almazán basin. The red line indicates the location of Miñana fossil site and its correlation to the GPTS.

Figure 8

Magnetostratigraphic map of the Gómara monocline. Magnetic reversals had been extended through the monocline following traceable levels. Black bands mark the normal magnetic polarity intervals. The magnetostratigraphic sampling track has been marked and corresponds to the Almazul and Mazaterón sections, unified as Miñana transect in this figure. The other sections shown correspond to the ones where sedimentation rates were calculated (Fig. 9). Geological formations are included. A widening of the magnetic reversals towards the NW, where clastic formations dominate can be distinguished.

Figure 9

Sedimentation rates resulting from plotting stratigraphic thicknesses against magnetostratigraphic ages for 4 key transects (location in Fig. 8). These sections encompass the most characteristic formations and large-scale architectures of the Almazán Basin. Polygons indicate the sedimentary environments, which nearly coincide with the formations. The stacking pattern is drawn in circles, and its perimeter color indicates the section. The numbers refer to Sedimentation Rates, (in $\mathrm{cm} / \mathrm{kyr}$ ), and are calculated within magnetic reversals, which are the vertical underlying white or grey stripes. Each section has its own thickness coordinates origin, only for representative purposes.

Figure 10

Summary of the evolution of tectonic uplift and subsidence for the four Paleogene tectonic domains during the four depositional sequences (right). Subsidence and uplift are estimated from the architectural arrangement. The syn-sedimentary styles and the development of alluvial fans as consequence of the uplift of nearby structures are shown. MCT, Main Cameros Thrust; SCT, South Cameros Thrust; C A/T, Cardejón Anticline/Thrust; ATT, La Alameda-Tapiela Thrust; GM, Gómara Monocline; TA, Torlengua Anticline; AAM, Almazán-Arcos Monoclines (see Fig.1 for location). 


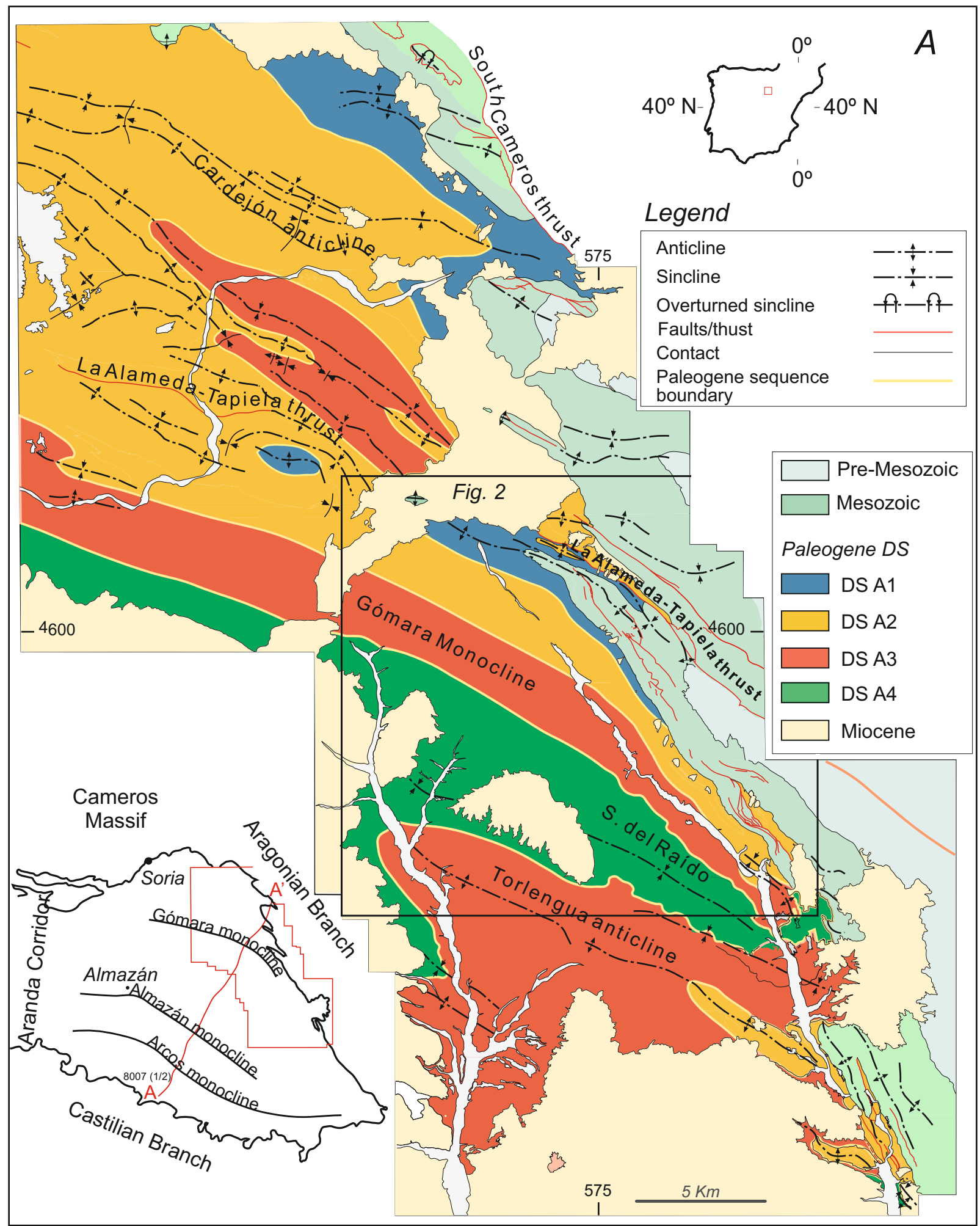




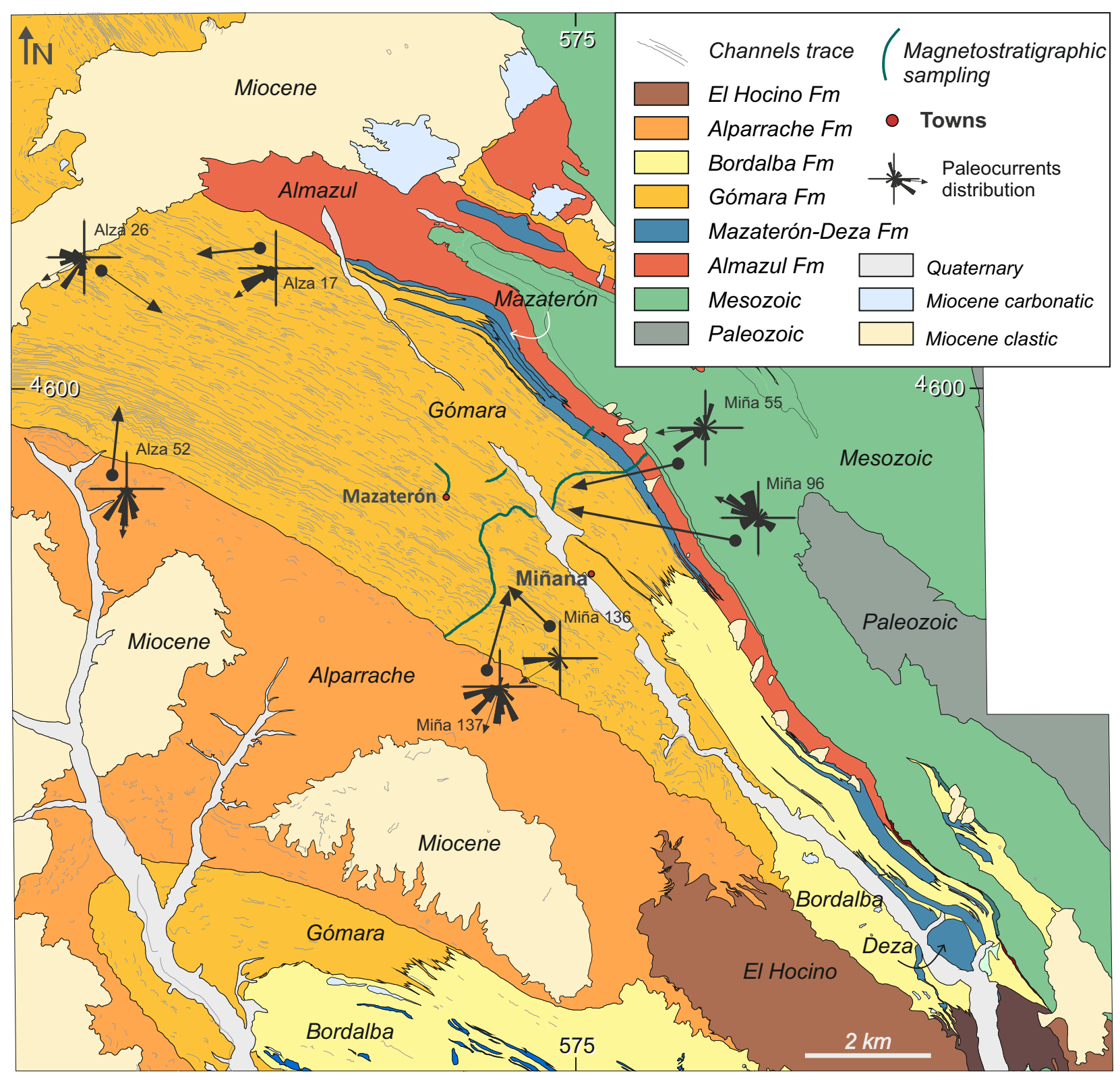



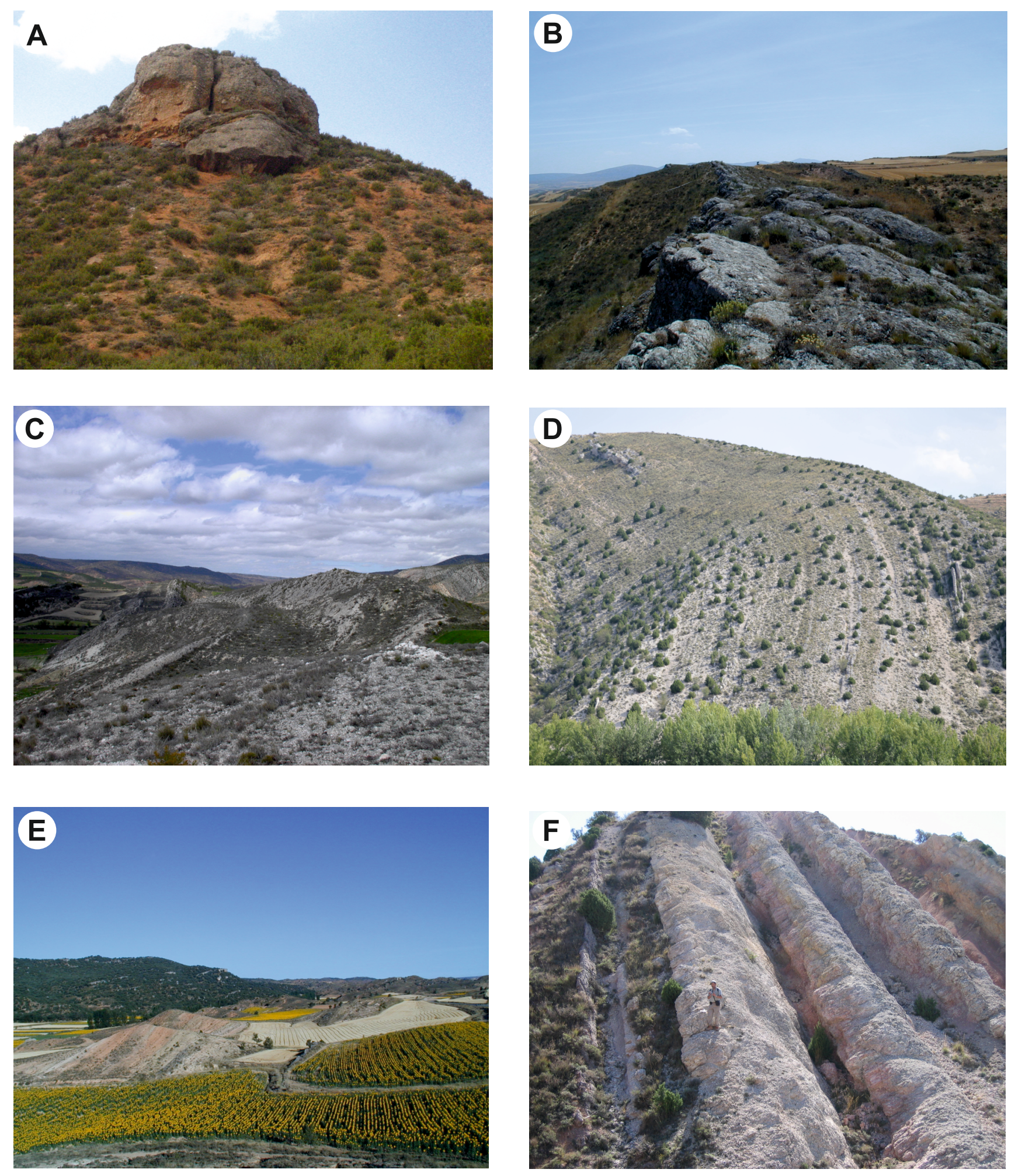

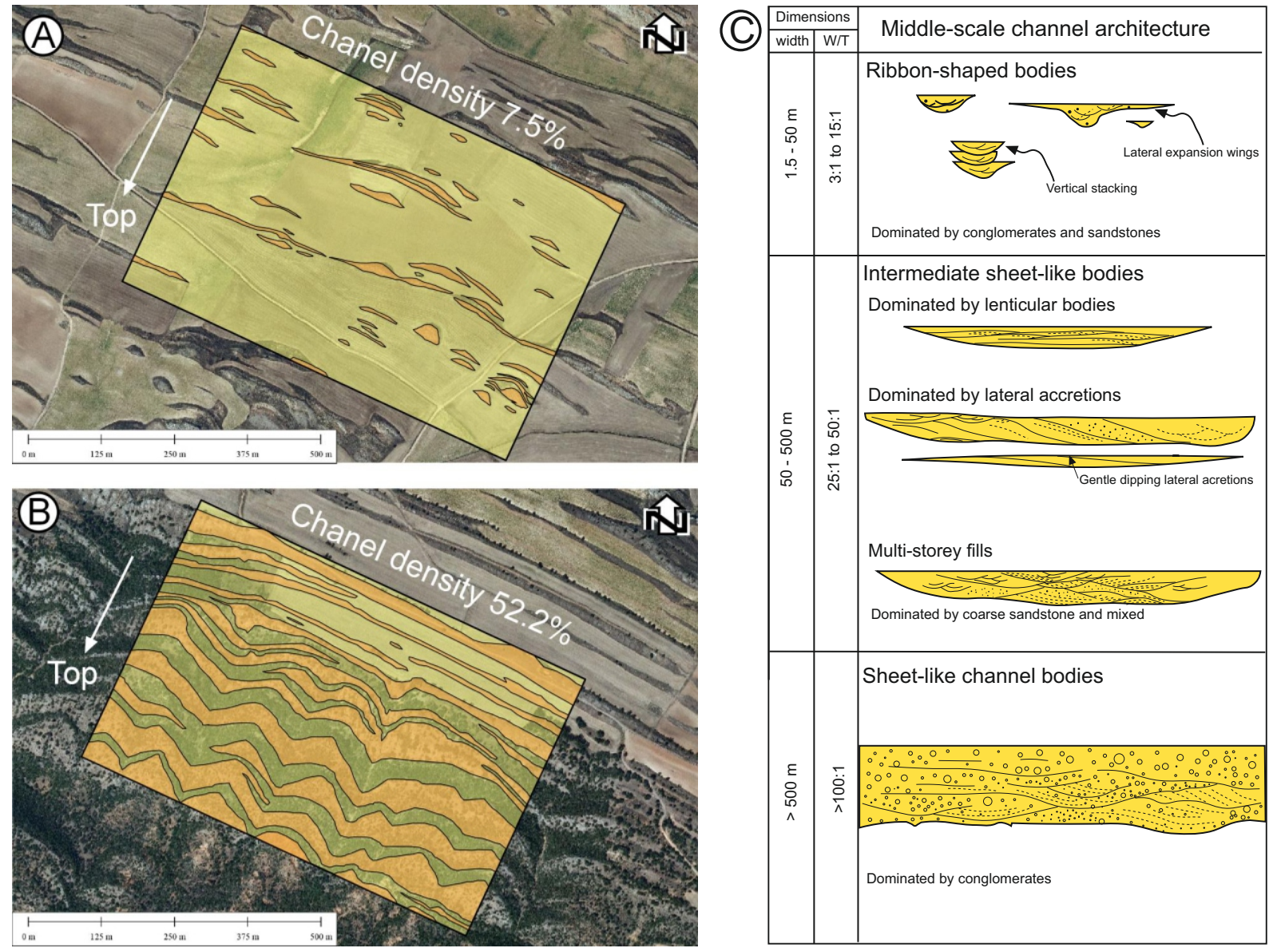

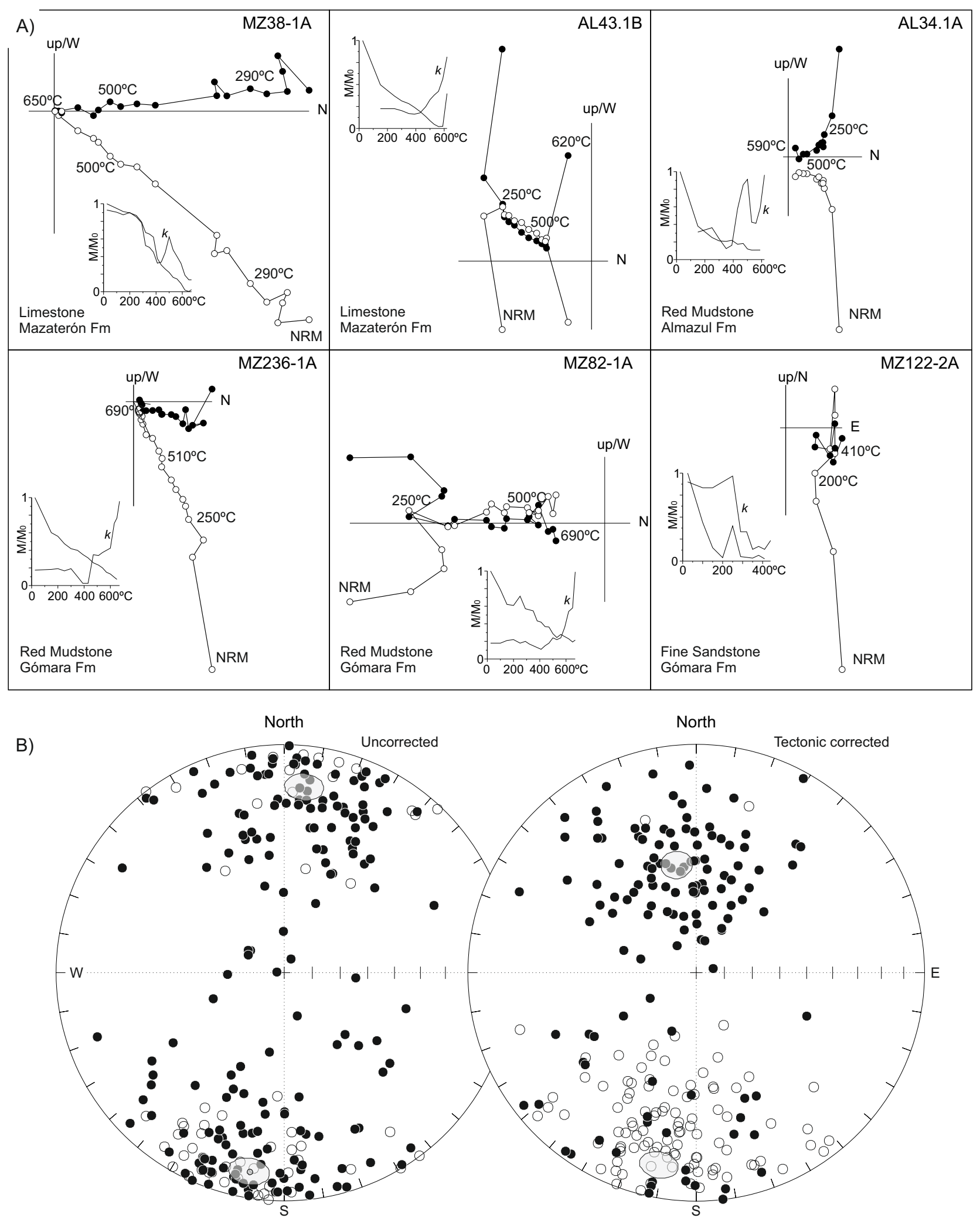

\begin{tabular}{c|c|c|c|c|c} 
Polarity & $\mathbf{N}$ & $\mathbf{D e c}$ & $\mathbf{I n c}$ & Ks & $\boldsymbol{\alpha 9 5}$ \\
\hline Normal & 104 & 6.3 & 21.2 & 7.1 & 5.6 \\
\hline Reverse & 130 & 190.0 & 15.0 & 5.7 & 5.7
\end{tabular}

\begin{tabular}{c|c|c|c|c|c} 
Polarity & $\mathbf{N}$ & Dec & Inc & Ks & $\alpha 95$ \\
\hline Normal & 104 & 349.9 & 50.8 & 8.3 & 5.1 \\
\hline Reverse & 130 & 191.0 & -18.1 & 6.1 & 5.5
\end{tabular}



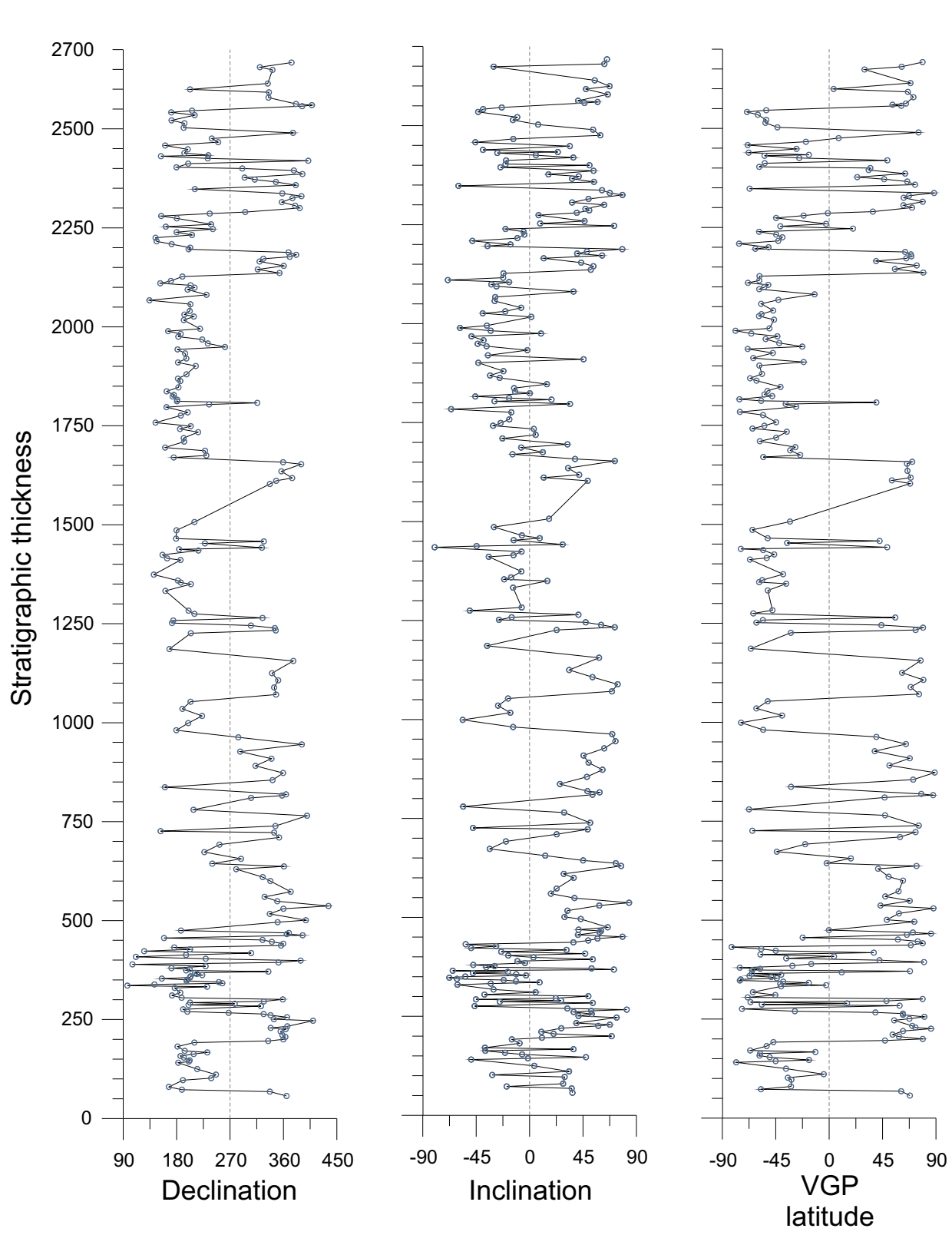

Polarity

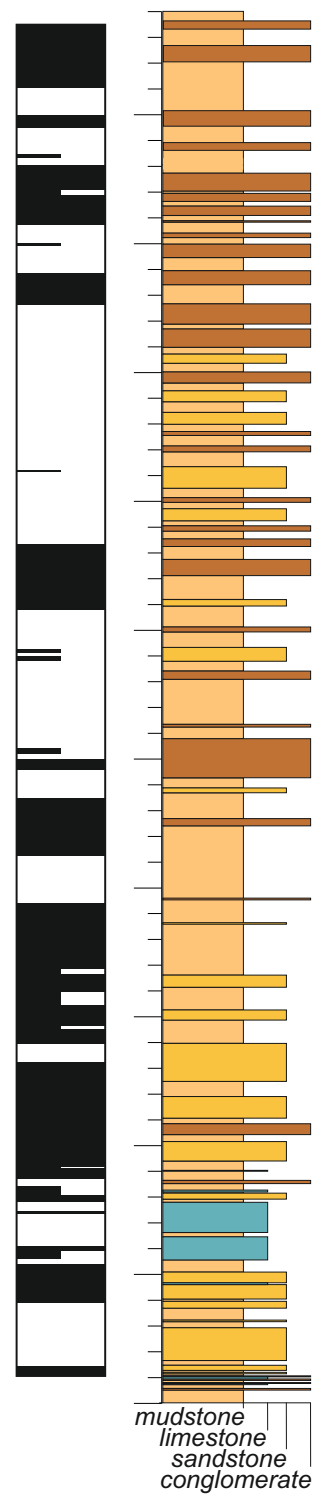


GTS 2012

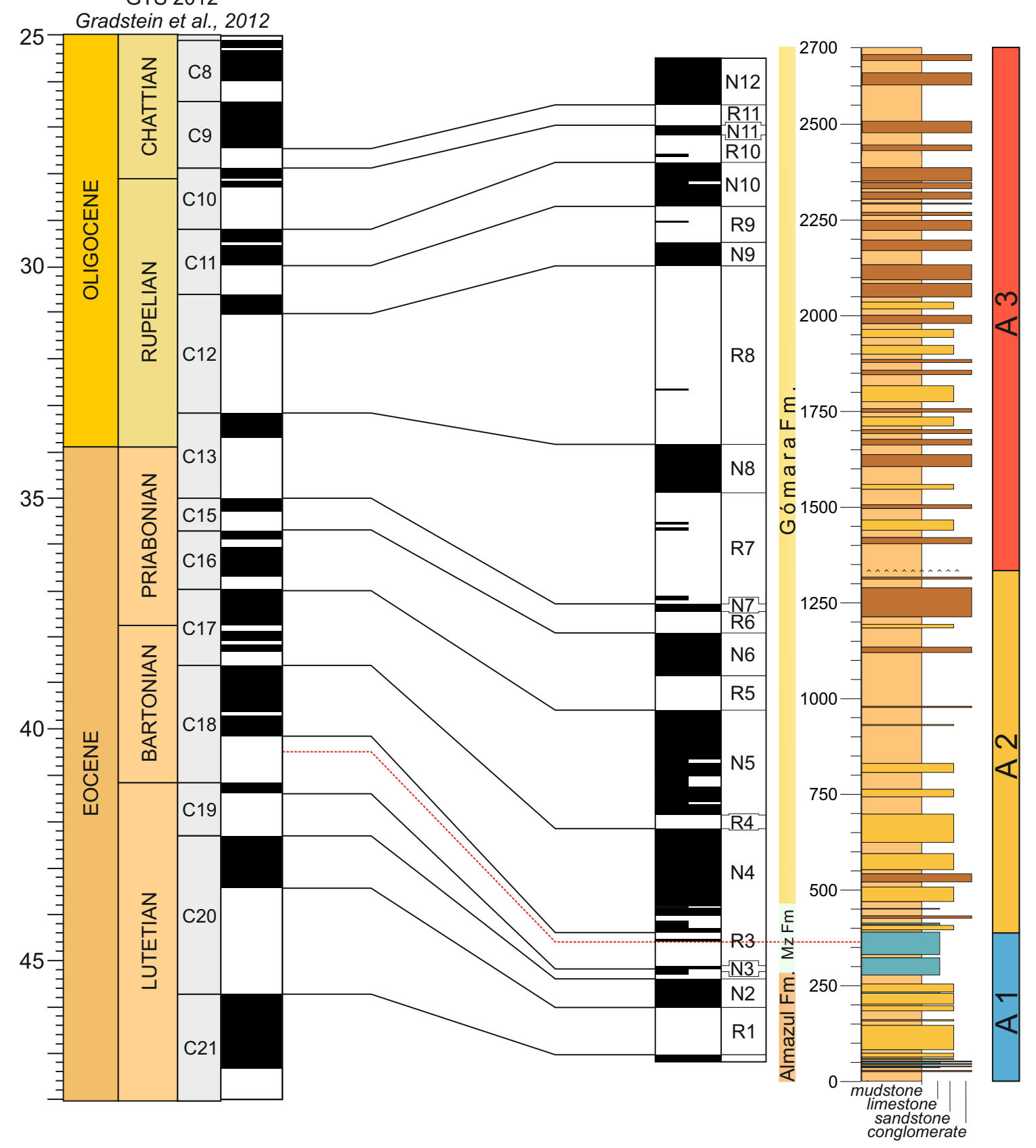




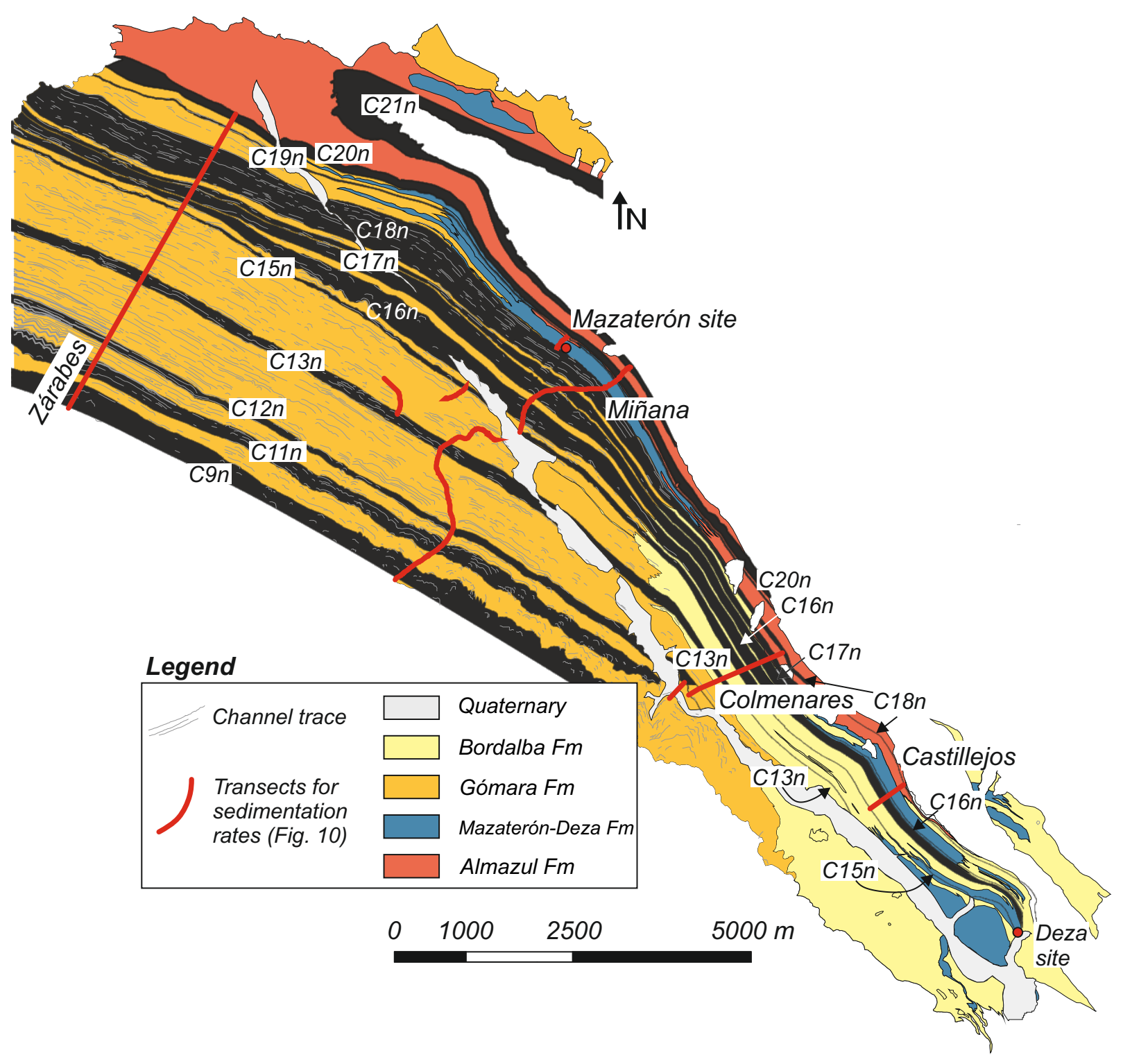




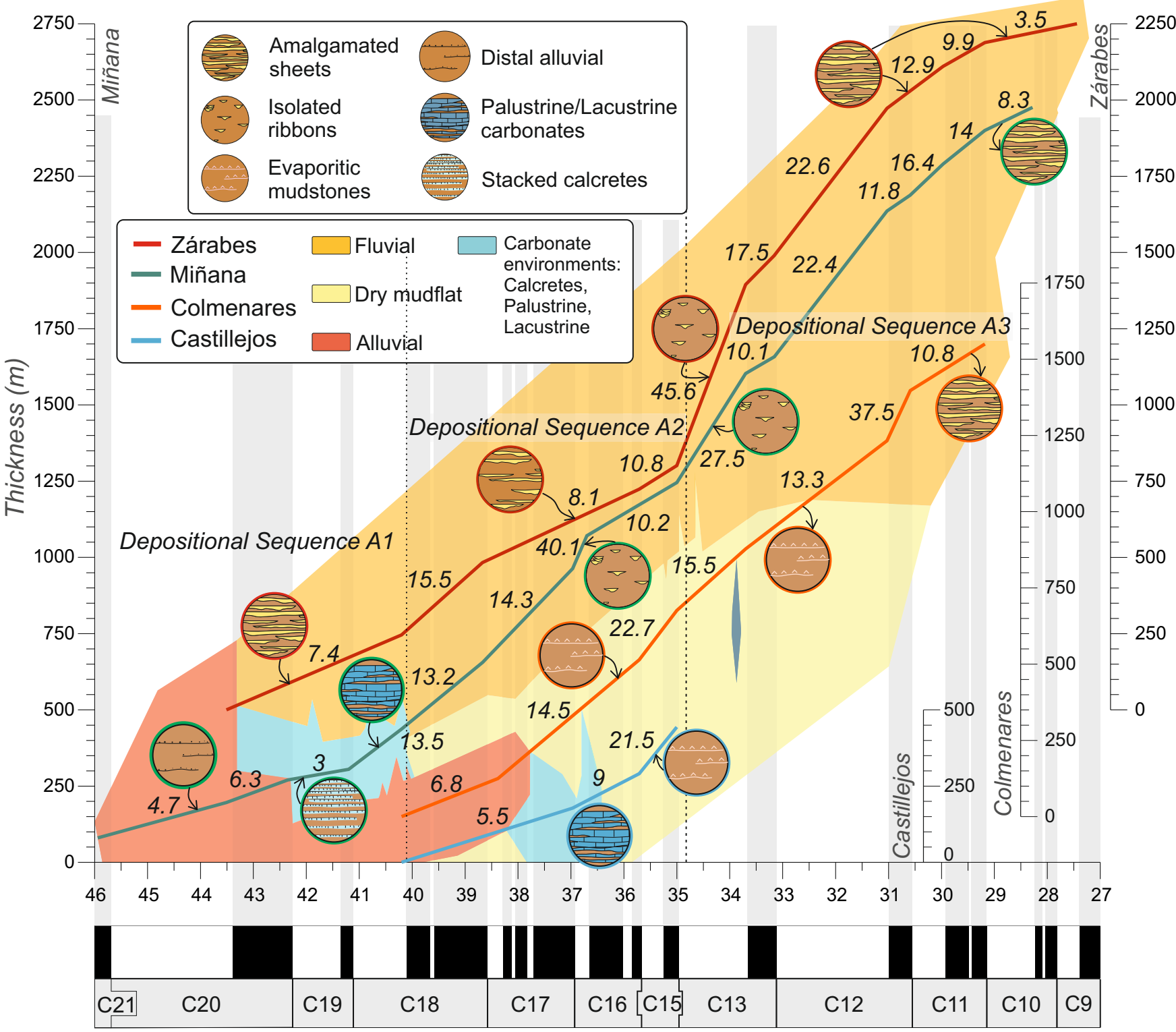

Age (Ma) GPTS 2012 (Gradstein et al., 2012) 


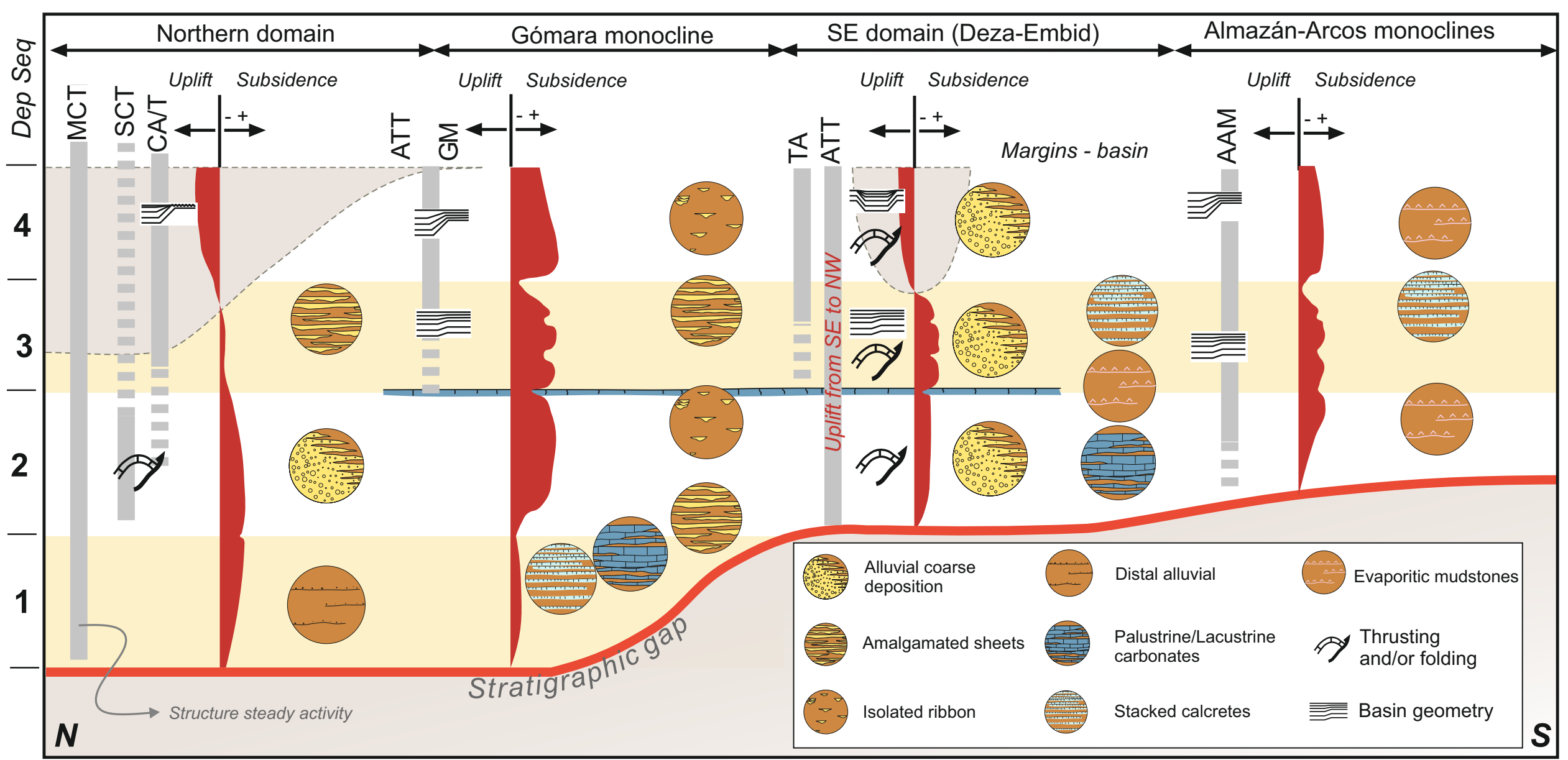

FOR REVIEW PURPOSES ONLY 


\begin{tabular}{|r|l|r|r|r|}
\hline \# Box & $\begin{array}{l}\text { Depositional } \\
\text { sequence }\end{array}$ & $\begin{array}{l}\text { Box area } \\
\left(\mathrm{km}^{2}\right)\end{array}$ & $\begin{array}{l}\text { Channel } \\
\text { fill area } \\
\left(\mathrm{km}^{2}\right)\end{array}$ & $\begin{array}{l}\text { Channel } \\
\text { density (\%) }\end{array}$ \\
\hline 1 & A2 & 0.35 & 0.020 & 5.64 \\
\hline 2 & A2 & 0.35 & 0.022 & 6.40 \\
\hline 3 & A2 & 0.35 & 0.026 & 7.52 \\
\hline 4 & A2 & 0.35 & 0.015 & 4.42 \\
\hline 5 & A3 & 0.35 & 0.155 & 44.40 \\
\hline 6 & A3 & 0.35 & 0.116 & 33.23 \\
\hline 7 & A3 & 0.35 & 0.183 & 52.22 \\
\hline 8 & A3 & 0.35 & 0.077 & 22.04 \\
\hline & & & & \\
\hline
\end{tabular}

Table 1: Channel density calculated for 8 boxes. 4 in DS A2 and 4 in DS A3. 


\begin{tabular}{|c|c|c|c|c|c|c|c|c|}
\hline \multicolumn{9}{|c|}{ Zárabes section } \\
\hline Interval & $\begin{array}{l}\text { Initial } \\
\text { Age } \\
\text { (Ma) }\end{array}$ & $\begin{array}{l}\text { Final } \\
\text { Age } \\
\text { (Ma) }\end{array}$ & $\begin{array}{l}\text { Thickness } \\
\text { increase } \\
\text { (m) }\end{array}$ & $\begin{array}{l}\text { Acummulated } \\
\text { thickness (m) }\end{array}$ & $\begin{array}{c}\text { Age } \\
\text { increase } \\
\text { (Ma) }\end{array}$ & $\begin{array}{l}\text { Sedimentation } \\
\text { rate }(\mathrm{cm} / \mathrm{kyr})\end{array}$ & $\begin{array}{c}\text { Dip } \\
\text { direction }\end{array}$ & Dip \\
\hline 1 & 43.51 & 40.2 & 245.73 & 245.73 & 3.31 & 7.42 & 206 & 25 \\
\hline 2 & 40.2 & 38.67 & 237.47 & 483.2 & 1.53 & 15.52 & 200 & 30 \\
\hline 3 & 38.67 & 35.71 & 240.65 & 723.85 & 2.96 & 8.13 & 203 & 35 \\
\hline 4 & 35.71 & 35 & 77.3 & 801.15 & 0.71 & 10.89 & 206 & 35 \\
\hline 5 & 35 & 33.7 & 593.63 & 1394.78 & 1.3 & 45.66 & 206 & 35 \\
\hline 6 & 33.7 & 33.16 & 94.96 & 1489.74 & 0.54 & 17.59 & 206 & 35 \\
\hline 7 & 33.16 & 31.03 & 483.14 & 1972.88 & 2.13 & 22.68 & 208 & 30 \\
\hline 8 & 31.03 & 29.97 & 137.44 & 2110.32 & 1.06 & 12.97 & 208 & 25 \\
\hline 9 & 29.97 & 29.18 & 78.24 & 2188.56 & 0.79 & 9.90 & 209 & 20 \\
\hline 10 & 29.18 & 27.44 & 61.58 & 2250.14 & 1.74 & 3.54 & 208 & 20 \\
\hline \multicolumn{9}{|c|}{ Colmenares section } \\
\hline Interval & $\begin{array}{l}\text { Initial } \\
\text { Age } \\
\text { (Ma) }\end{array}$ & $\begin{array}{l}\text { Final } \\
\text { Age } \\
\text { (Ma) }\end{array}$ & $\begin{array}{l}\text { Thickness } \\
\text { increase } \\
\text { (m) }\end{array}$ & $\begin{array}{l}\text { Acummulated } \\
\text { thickness (m) }\end{array}$ & $\begin{array}{c}\text { Age } \\
\text { increase } \\
\text { (Ma) }\end{array}$ & $\begin{array}{l}\text { Sedimentation } \\
\text { rate }(\mathrm{cm} / \mathrm{kyr})\end{array}$ & $\begin{array}{c}\text { Dip } \\
\text { direction }\end{array}$ & Dip \\
\hline 1 & 40.2 & 38.38 & 124.98 & 124.98 & 1.82 & 6.87 & 55 & 60 \\
\hline 2 & 38.38 & 35.71 & 389.19 & 514.17 & 2.67 & 14.58 & 55 & 75 \\
\hline 3 & 35.71 & 35 & 161.73 & 675.9 & 0.71 & 22.78 & 55 & 85 \\
\hline 4 & 35 & 33.7 & 201.79 & 877.69 & 1.3 & 15.52 & 55 & 90 \\
\hline 5 & 33.7 & 31.03 & 354.73 & 1232.42 & 2.67 & 13.29 & 233 & 82 \\
\hline 6 & 31.03 & 30.59 & 164.99 & 1397.41 & 0.44 & 37.50 & 232 & 79 \\
\hline 7 & 30.59 & 29.18 & 152.57 & 1549.98 & 1.41 & 10.82 & 232 & 45 \\
\hline \multicolumn{9}{|c|}{ Castillejos section } \\
\hline Interval & $\begin{array}{l}\text { Initial } \\
\text { Age } \\
\text { (Ma) }\end{array}$ & $\begin{array}{l}\text { Final } \\
\text { Age } \\
\text { (Ma) }\end{array}$ & $\begin{array}{l}\text { Thickness } \\
\text { increase } \\
\text { (m) }\end{array}$ & $\begin{array}{l}\text { Acummulated } \\
\text { thickness (m) }\end{array}$ & $\begin{array}{c}\text { Age } \\
\text { increase } \\
\text { (Ma) }\end{array}$ & $\begin{array}{l}\text { Sedimentation } \\
\text { rate }(\mathrm{cm} / \mathrm{kyr})\end{array}$ & $\begin{array}{c}\text { Dip } \\
\text { direction }\end{array}$ & Dip \\
\hline 1 & 40.2 & 36.97 & 177.54 & 177.54 & 3.23 & 5.50 & 233 & 61 \\
\hline 2 & 36.97 & 35.71 & 113.23 & 290.77 & 1.26 & 8.99 & 233 & 61 \\
\hline 3 & 35.71 & 35 & 152.75 & 443.52 & 0.71 & 21.51 & 233 & 61 \\
\hline
\end{tabular}

